\title{
A DECOMPOSITION OF GLOBAL LINKAGES IN FINANCIAL MARKETS OVER TIME*
}

\author{
Kristin J. Forbes and Menzie D. Chinn
}

\begin{abstract}
This paper tests if real and financial linkages between countries can explain why movements in the world's largest markets often have such large effects on other financial markets, and how these cross-market linkages have changed over time. It estimates a factor model in which a country's market returns are determined by global, sectoral, and crosscountry factors (returns in large financial markets) and by country-specific effects. Then it uses a new data set on bilateral linkages between the world's five largest economies and approximately 40 other markets to decompose the cross-country factor loadings into direct trade flows, competition in third markets, bank lending, and foreign direct investment. In the latter half of the 1990s, bilateral trade flows are large and significant determinants of how shocks are transmitted from large economies to other stock and bond markets. Bilateral foreign investment is usually insignificant. Therefore, despite the recent growth in global financial flows, direct trade still appears to be the most important determinant of how movements in the world's largest markets affect financial markets around the globe.
\end{abstract}

\section{Introduction}

$\mathrm{I}^{\mathrm{r}}$ $n$ the first half of 2002, the United States was buffeted by a series of negative shocks-from disappointing economic growth, to terrorist threats and uncertainty about a potential war with Iraq, to continued fallout from a series of financial scandals that raised broader concerns about corporate governance. As a result, the U.S. stock market fell by approximately $17 \%$ over the first 6 months of the year. ${ }^{1}$ Many other markets around the world declined in harmony; over the same 6-month period, Finland's stock market fell by $30 \%$, Ireland's by $14 \%$, Mexico's by $11 \%$, and Hong Kong's by $6 \%$. Other stock markets, however, performed relatively well and appeared to be insulated from the flow of negative news emanating from the United States. For example, over the same period Iceland's stock market experienced positive returns of 26\%, South Africa's of 21\%, South Korea's of $12 \%$, and Colombia's of $11 \%$. Shocks to the world's largest economies and their financial markets often spread to some markets, whereas markets in other countries are relatively insulated.

This paper examines if real and financial linkages between countries can explain why the world's largest financial markets often appear to have such large, yet diverse, effects on other financial markets, and how these crossmarket linkages have changed over time. More specifically, the paper attempts to answer four questions. First, how important are cross-country linkages with large financial

Received for publication March 6, 2003. Revision accepted for publication September 9, 2003.

* MIT and NBER; and University of Wisconsin and NBER, respectively.

Thanks to Robin Brooks, Ashoka Mody, Fabrizio Perri, Andy Rose, Beatrice Weder, and participants at the Global Linkages Conference for helpful comments and suggestions. We are also grateful to Andy Rose, Sergio Schmukler, and Frank Warnock for sharing their data sets.

${ }^{1}$ Aggregate stock market indices reported by Datastream. See section IV for additional data information. markets, as compared to global and sectoral factors, in explaining financial market returns in countries around the world? Second, how important are bilateral trade flows, trade competition in third markets, bank lending, and investment exposure in explaining these cross-country linkages? Third, how has the relative importance of these various global linkages changed over time? Finally, how does the relative importance of these global linkages differ across stock markets and bond markets?

In order to answer these questions, this paper begins by developing a factor model of market returns in different countries. It assumes that a country's market returns are a function of cross-country factors (returns in other large financial markets), global factors (world stock market returns, global interest rates, oil prices, gold prices, and commodity prices), sectoral factors (stock returns for 14 sectoral indices), and country-specific effects. After estimating the importance of these factors for different countries and regions, the paper then focuses on the estimated crosscountry linkages between the five largest economies (France, Germany, Japan, the U.K. and U.S.) and approximately 40 developed countries and emerging markets around the world. It decomposes these cross-country linkages into four specific bilateral linkages: two real linkages (direct trade flows and competition in third markets) and two financial linkages (bank lending and foreign direct investment). After measuring the importance of each of these factors and bilateral linkages in stock markets between 1986 and 2000, the paper than examines how their relative importance has changed over time and differs in bond markets.

The paper finds that both cross-country factors and sectoral factors are important determinants of stock and bond returns in countries around the world (although it is often difficult to differentiate between these two sets of factors). Not surprisingly, movements in the largest regional economy tend be the most important cross-country factor for nearby countries (such as the U.S. market for the Americas), although movements in the U.S. market are also important for most regions. There is also some evidence that in the latter half of the 1990s, sectoral factors gained importance in most regions, while the Japanese factor lost importance.

Results from the second-stage regressions that decompose the cross-country factor loadings into different real and financial linkages find that from 1986 to 1990 and from 1991 to 1995 , bilateral linkages are fairly unimportant and estimation results are highly sensitive to model specification. From 1996 to 2000, however, bilateral linkages through trade and finance become more significant determinants of how shocks are transmitted from large economies 
to markets around the world. More specifically, direct trade flows appear to be the strongest and most important determinant of cross-country linkages in both stock and bond markets. Bilateral bank lending and trade competition in third markets can also be significant determinants of crosscountry linkages, although the importance of these bilateral linkages fluctuates across asset markets and model specifications. Bilateral foreign investment, however, is generally not a significant determinant of cross-country linkages. These results establish a connection between highfrequency movements in financial markets and lowerfrequency real variables. They also suggest that despite the recent growth in capital flows between countries, direct trade linkages are still more important than financial linkages in determining how shocks to the world's largest economies affect markets around the globe.

One major contribution of this study is the development of a new data set on bilateral trade and financial linkages between the world's largest economies and approximately 40 developed countries and emerging markets. Although information on bilateral trade flows has been available for years, other variables are fairly new to this literature, such as the statistics measuring bilateral investment positions and trade competition in third markets based on four-digit SITC industry information. ${ }^{2}$ Perhaps most important, this is the first study to simultaneously control for direct trade flows, trade competition in third markets, bank lending, and foreign direct investment, when attempting to explain crosscountry linkages. Other papers have controlled for one or two of these linkages to examine a range of questions, but because the four bilateral linkage variables could be highly correlated, omitting a subset of these variables could severely bias coefficient estimates. Therefore, by simultaneously controlling for all four bilateral linkages, this paper should provide more accurate estimates of the importance of different types of trade and financial channels in explaining cross-country comovement in financial markets.

The remainder of the paper is as follows. Section II briefly reviews related literature. Section III develops the models and estimation framework. Section IV describes the data set and the construction of several new variables. It also examines trends in various bilateral linkages for different sets of countries. Section V provides initial results for stock markets over the full sample period from 1986 to 2000, and section VI examines how the importance of various global linkages has evolved over time. Section VII performs a similar analysis for bond markets and compares results with those for stock markets. Section VIII summarizes an extensive series of sensitivity tests. Section IX concludes by summarizing how this paper's new data set and the corresponding results provide insights on the changing nature of

\footnotetext{
${ }^{2}$ Forbes (2002) also constructs this trade competition variable for a series of "crisis countries" between 1997 and 2000. Mody, Razin, and Sadka (2002) is one of the few papers to use the same foreign investment database.
}

integration between the world's largest economies and financial markets around the world.

\section{Related Literature}

This paper builds on an extensive literature that can be roughly grouped into four categories: asset market comovement and financial integration, business cycle synchronization and real integration, firm-level exposure to real and financial shocks, and the international transmission of crises. ${ }^{3}$ The literature on cross-country comovement in asset returns can be traced back to the international-capital assetpricing model, which posits that in completely segmented markets, local asset returns will be based on local factors. With integrated capital markets, however, expected asset returns are determined by the asset's covariance with the world market portfolio. A large body of research has therefore attempted to identify how the integration of previously segmented markets has changed patterns of cross-country equity correlations. Increased integration with global markets, however, does not necessarily generate increased correlations between domestic and global asset returns.

One reason why integration may not generate increased correlations is differences in industrial structures. Roll (1992) argues that industry structure and concentration are important determinants of a country's stock market behavior, and that sets of countries with more similar industrial compositions tend to have more highly correlated stock market returns. In subsequent work, there has been an active debate on the relative importance of industry effects versus country-specific effects in explaining cross-country correlations and volatility. ${ }^{4}$ One recent focus of this debate is whether the increased importance of sectoral factors in the late 1990s represents a long-term trend or cyclical effects from the bubble in telecommunications, media, and technology (TMT).

In addition to this literature focusing on stock market returns and financial market comovement, there is also an extensive literature examining "synchronization" and the cross-country comovement in business cycles and real variables. ${ }^{5}$ Some of these papers, such as Kose, Otrok, and Whiteman (2003), examine how global integration has affected cross-country correlations in output, consumption, and investment. Other papers attempt to explain these correlations in terms of country characteristics and specific measures of integration, such as trade, asset diversification, or output composition. A priori, it is unclear if greater integration would increase or decrease business cycle correlations, but most of the empirical work on this subject

\footnotetext{
${ }^{3}$ See Forbes and Chinn (2003) for a more detailed summary of the literature reviewed in this section. Also see Karolyi and Stulz (2003) and Bekaert and Harvey (2002) for detailed surveys of related work.

${ }^{4}$ See Brooks and Del Negro $(2002,2003)$ for recent reviews of these debates.

${ }^{5}$ See Imbs (2003) for a more thorough review of this literature.
} 
finds that greater integration through trade and/or finance tends to increase correlations.

Connecting this branch of literature on real integration and business cycles with the previously mentioned literature on asset market comovement is a related literature on firm-level exposure to exchange rate movements and real variables. ${ }^{6}$ Most of this work finds that only a small percentage of firms are significantly exposed to exchange rate movements, and that the relationship between exchange rate exposure and real linkages with other countries (such as trade) is either weak or nonexistent. Brooks and Del Negro (2003) is one of the few papers to document a significant relationship between trade exposure and firm-level stock returns over annual periods, a connection that is also documented at the country level in this paper.

While most of the literature discussed above has focused on the determinants of cross-country correlations (in either financial markets or real variables) over long periods of time or around periods of increased financial integration, another, related literature has examined asset market comovement during financial crises. Much of this work has focused on "contagion" and the international transmission of crises. Several of these papers attempt to measure the different channels by which a shock to one country spreads to other countries and are closely related to the decomposition of bilateral linkages performed in this paper. ${ }^{8}$ For example, Eichengreen and Rose (1999), Glick and Rose (1999), and Forbes (2002) focus on the role of trade in the transmission of currency crises. Van Rijckeghem and Weder $(2001,2003)$ examine the role of bank lending as well as trade. Forbes (2004) is one of the few papers to measure the importance of these trade and financial channels in the transmission of crises at the firm level.

Many of these papers find that trade linkages between countries-both direct trade flows and competition in third markets-were important determinants of how crises affected other countries. Some papers have also argued, however, that bilateral financial flows may be even more important than trade flows, although it can be difficult to isolate their independent effects. One limitation of all of these studies (which most authors candidly admit) is that because many bilateral linkages are highly correlated and difficult to measure, studies that only include a subset of these linkages can have problems with omitted variable bias. For example, studies that control for trade linkages between countries, but not investment, are likely to overstate the importance of trade linkages.

\footnotetext{
${ }^{6}$ See Dominguez and Tesar (2001) for a detailed review of this literature.

${ }^{7}$ See Claessens and Forbes (2001) for a series of papers on this subject. In particular, see Claessens, Dornbusch, and Park (2001) for a detailed review of the literature, and Forbes and Rigobon (2002) for a critical assessment of tests for contagion based on correlation coefficients.

${ }^{8}$ See Forbes (2002) for a much more detailed review of the literature discussed in this paragraph.
}

This paper is the first study to simultaneously control for direct trade flows, competition in third markets, bank lending, and foreign direct investment when measuring asset market comovements and the international transmission of shocks. This approach should therefore reduce any omitted variable bias in the estimated importance of each of these bilateral linkages. Even this more comprehensive analysis, however, is incomplete, for there are numerous other crosscountry linkages that are not included in this study because bilateral data are unavailable. For example, Kaminsky, Lyons, and Schmukler (2001) show that mutual fund investments can be important mechanisms for the cross-country transmission of crises. Karolyi (2004) shows that crosslisting through American depositary receipts (ADRs) can affect stock market integration. Multinational exposure across borders or trade credit could also be important transmission mechanisms. All of these variables are likely to be correlated with bilateral foreign investment or trade flows, potentially biasing the relevant coefficient estimates. Therefore, although this paper's analysis of bilateral linkages is more comprehensive than previous work, additional bilateral linkages that are not included in this analysis could still affect estimates.

\section{Model and Estimation Framework}

This section describes the two-stage modeling framework used to estimate the importance of different cross-country linkages over long periods, as well as how their importance has changed over time. In the first stage, we estimate a factor model of returns, controlling for cross-country and global factors, and occasionally sectoral factors. In the second stage, we decompose the estimated cross-country factor loadings into four types of bilateral linkages: import demand, trade competition, bank lending, and foreign investment.

Returns in two countries could comove due to a number of factors. First, returns in two countries could comove because shocks to one country are transmitted to other countries through cross-country linkages, such as bilateral trade, export competition in third markets, bilateral bank lending, or bilateral investment flows. Second, returns in both countries could be affected by global shocks, such as changes in: global stock markets, the world interest rate, oil prices, other commodity prices, or global risk aversion. Third, returns in both countries could be affected by sectoral shocks that simultaneously affect all countries that produce in or have exposure to the given sector. As discussed in section II, one sectoral shock that has recently received substantial attention is the bubble in TMT in the late 1990s. Although the cross-country linkages are the focus of this paper, it is important to control for global and/or sectoral shocks in order to accurately estimate the magnitude of these linkages and avoid spuriously capturing changes in other factors that affect comovement. 
In order to isolate the importance of cross-country linkages, this paper uses a factor model of returns that controls for up to three sets of factors: cross-country, global, and sectoral. It also allows market returns in each country to be determined by a country-specific effect. For each country $i$, asset returns $\left(R_{i t}\right)$ at each time $t$ can be expressed as:

$$
R_{i t}=\alpha_{i}+\sum_{c=1}^{C} \beta_{i}^{c} f_{t}^{c}+\sum_{g=1}^{G} \phi_{i}^{g} f_{t}^{g}+\sum_{s=1}^{S} \gamma_{i}^{s} f_{t}^{s}+\varepsilon_{i t},
$$

with $E\left[\varepsilon_{i t}\right]=0, E\left[\varepsilon_{i t}^{2}\right]=\sigma_{i}^{2}$, and $E\left[\varepsilon_{i t} \varepsilon_{j t}\right]=\sigma_{i j}^{2}$ for each pair of countries $i$ and $j$ with $i \neq j$. The $f_{t}^{c}$ are the $C$ cross-country factors, corresponding to each large country $c$; the $f_{t}^{g}$ are the $G$ global factors; the $f_{t}^{s}$ are the $S$ sectoral factors; $\beta_{i}^{c}, \phi_{i}^{g}$, and $\gamma_{i}^{s}$ are the country-specific factor loadings for the cross-country, global, and sectoral factors, respectively; $\alpha_{i}$ is a country-specific effect; and $\varepsilon_{i t}$ is a normally distributed error term, with errors not necessarily independent across countries. Factor loadings are therefore assumed to be constant for each country, but can vary across countries.

The model in equation (1) is assumed to hold for each of the smaller countries $i$ in the world, with $i=1,2, \ldots, I$. The $C$ countries that are defined as the cross-country factors are large countries in which shocks are expected to have the greatest spillover effects in countries around the world. These $C$ larger countries are then excluded from the set of countries included as $i$. For example, Chile and the Philippines could be two countries included as countries $i$, and the United States and Japan could be two countries included as countries $c$ but not included as $i$. Estimates of $\beta_{i}^{c}$ should therefore capture the effect of movements in the U.S. and Japanese markets on the Chilean and Philippine markets, with minimal feedback effect from $R_{i t}$ to $f_{t}^{c} .9$ The model focuses on the effect of shocks to larger countries on smaller countries, rather than estimating simultaneous equations between all countries in the world. That is because limited data are available on bilateral linkages between most smaller countries in the world.

One potential problem with equation (1), however, is that the cross-country, global, and sectoral factors can be highly correlated, making it difficult to isolate the individual effect of each set of factors. More specifically, if a large country $c$ that is a major producer (or purchaser) in a given industrial sector experiences a significant shock, the country-specific shock could not only affect other countries through crosscountry linkages, but also simultaneously affect certain sectors globally. For example, the United States produces a major share of global output and is a major consumer in the electronics industry. The impact of a shock to the U.S.

\footnotetext{
${ }^{9}$ There are, however, unusual occasions when shocks to smaller countries affect larger countries-such as when the 1998 Russian crisis affected bond spreads in the United States. In these cases, estimates of $\beta_{i}^{c}$ should be interpreted as correlations between two countries $c$ and $i$, instead of direct effects of country $c$ on country $i$.
}

economy on other countries could therefore be largely captured in the sectoral factor for electronics, reducing estimates of any direct cross-country effects of the U.S. on other economies. Similarly, if a shock to a major economy (such as the U.S.) spreads to most other countries in the world, this could appear to be a global shock, even though it is technically just a country-specific shock in a major economy. In order to control for this potential multicollinearity when estimating the factor loadings, we examine the correlation structure between each pair of factors, as well as estimate equation (1) without the sectoral and/or global factors.

After obtaining estimates of the cross-country loadings $\beta_{i}^{c}$ (either with or without controls for the full set of global and sectoral factors) for each pair of small countries $i$ and large countries $c$ (an $I \times C$ matrix of $\beta$ 's), we decompose these cross-country loadings into different types of bilateral linkages. We focus on four different channels through which shocks to a large country $c$ could affect a smaller country $i$. First, shocks to country $c$ could affect country $c$ 's demand for imports from country $i$. Second, shocks to country $c$, and especially shocks to country $c$ that affect country $c$ 's exchange rate, could affect the relative price of country $c$ 's exports and therefore affect country $i$ through trade competition in third markets. Third, shocks to country $c$ could affect bank lending from country $c$ into smaller countries $i$. Finally, shocks to country $c$ could affect flows of foreign investment from country $c$ into country $i$. There are obviously other channels that could link large and small countries, such as portfolio investment, trade credit, or multinational exposure. We focus on the mentioned four channels, however, not only because they have been highlighted in previous literature (as discussed in section II), but also because they are bilateral linkages for which data are available. ${ }^{10}$

In order to estimate the importance of these four different bilateral linkages in explaining the cross-country factor loadings, we use the following model ${ }^{11}$ :

$$
\begin{aligned}
\beta_{i}^{c}= & \alpha_{0}+\alpha_{1} \text { Import Demand }_{i}^{c} \\
& +\alpha_{2} \text { Trade Competition }_{i}^{c}+\alpha_{3} \text { Bank Lending }_{i}^{c} \\
& +\alpha_{4} \text { Foreign Investment }_{i}^{c}+\boldsymbol{\alpha}_{5} \mathbf{X}_{i}^{c}+\eta_{i c},
\end{aligned}
$$

where $\beta_{i}^{c}$ are the cross-country factor loadings [estimated in equation (1)] that measure the effect of asset returns in country $c$ on country $i$ after controlling for global and/or sectoral shocks; $\alpha_{0}$ is a constant term; Import Demand ${ }_{i}^{c}$ measures the importance to country $i$ of imports from country $i$ into country $c$; Trade Competition ${ }_{i}^{c}$ measures

\footnotetext{
${ }^{10}$ To the best of our knowledge, bilateral data on variables such as portfolio investment, trade credit, and multinational exposure are not available for the majority of countries in our data set.

${ }^{11}$ In earlier versions of this paper, we also estimated equation (2) as a panel model with annual data. As shown in Forbes and Chinn (2003), the key results are similar.
} 
the importance to country $i$ of export competition in third markets between country $i$ and country $c$; Bank Lending ${ }_{i}^{c}$ measures the importance to country $i$ of bank loans from country $c$; Foreign Investment ${ }_{i}^{c}$ measures the importance to country $i$ of total investment from country $c ; \mathbf{X}_{i}^{c}$ is a matrix including any country-specific factors in countries $i$ and/or $c$ that could affect linkages with other countries (such as capital controls); and $\eta_{i c}$ is a normally distributed error term.

Although, at first glance, one might expect that positive (negative) movements in large countries' asset markets would have positive (negative) effects on other countries' asset markets through each of the four bilateral linkage variables (so that $\alpha_{1}, \alpha_{2}, \alpha_{3}, \alpha_{4}>0$ ), theory suggests that the signs of these coefficients are a priori indeterminate and can only be ascertained empirically. For example, negative news about a large economy's growth prospects could cause negative returns in the large country's asset market. This could generate a contraction in lending and investment by banks and firms based in the large country as they strengthen balance sheets and build reserves for the expected slowdown. ${ }^{12}$ The resulting contraction in lending and investment in other countries would be expected to have a negative effect on asset returns in other countries, so that $\alpha_{3}$, $\alpha_{4}>0$. On the other hand, if the bad economic news about the large country caused banks and investors to keep their total volume of lending/investment fairly constant, but shift exposure away from the large economy to other countries, then they could increase lending/investment in other markets, so that $\alpha_{3}, \alpha_{4}<0$.

The sign of the coefficient on Trade Competition is also difficult to predict. If negative economic news in the large country corresponded to a depreciation of its exchange rate, this could give its exports a competitive advantage, therefore having a negative effect on expected asset returns in countries that are important trade competitors (so that $\alpha_{2}>$ $0)$. If the exchange rate movement is only partially passed through into export prices or is only expected to be shortlived, however, any effect on competitors could be minimal. Moreover, if the bad news in the large economy is any factor potentially hurting firm competitiveness-such as disappointing productivity growth, legislation increasing labor market rigidities, higher corporate taxes, or higher interest rates - this could improve the relative competitiveness of other countries' exports and generate a positive shock to other countries' asset markets, so that $\alpha_{2}<0$.

Even the sign of the coefficient on Import Demand is not clear-cut. In many cases, negative asset market returns in the large country reflect negative news about earnings prospects for domestic firms and reduced expectations for

\footnotetext{
12 Peek and Rosengreen (1997) provide evidence of this and show that after the 1990 Japanese stock market crash, Japanese banks reduced lending in the United States. Goldfajn and Valdés (1997) develop a formal model of how a shock to one country can cause financial intermediaries to liquidate loans to other countries.
}

economic growth. This could indicate decreased demand for imports and therefore cause negative returns in other countries that export to the large country, so that $\alpha_{1}>0$. Some news, however, could generate negative market movements in the large country, but not signify any changes in expectations about real variables such as growth or import demand. Other types of news could cause negative returns in the large economy, but simultaneously increase the country's demand for imports. For example, tariff reductions in the large economy might hurt earnings prospects of domestic firms (causing negative asset market returns), but increase the ability of other countries to import into the large economy (causing positive returns in other countries), so that $\alpha_{1}<0$. Therefore, the signs of all the coefficient estimates for the bilateral linkage variables in equation (2) are a priori indeterminate, and only empirical analysis will be able to establish the importance and direction of these bilateral linkages in the international transmission of asset market movements.

\section{Data}

In order to estimate the role of different global and bilateral linkages, we compile data from a number of sources. The data used to estimate the factor model of returns in equation (1) were compiled from DataStream, but many of the individual data series were based on different original sources that are incorporated into DataStream. Asset returns $\left(R_{i t}\right)$ are measured by weekly stock returns or weekly bond returns, both measured in either U.S. dollars or local currency. Stock returns are based on stock indices compiled by DataStream, which are weighted to be representative of all major markets in the given country. The bond data for developed countries is based on the total country return indices compiled by Morgan Stanley Capital International (MSCI) for 7-10 year bonds. The bond data for emerging markets is based on the EMBI Global total country return indices compiled by JPMorgan.

The cross-country, global, and sectoral factors in the factor model are also based on data series reported in DataStream. ${ }^{13}$ The cross-country factors are returns for the large countries $c$ in the asset market corresponding to the left-side variable. In other words, if $R_{i t}$ in equation (1) is U.S. dollar stock returns for country $i$, then $f_{t}^{c}$ is U.S. dollar stock returns for country $c$. For the countries indexed by $c$, we include the five largest countries in the world as ranked by GDP at either the start or end of the sample period (1985 or 2000). ${ }^{14}$ These five large countries $c$ are: France, Germany, Japan, the United Kingdom, and the United States.

\footnotetext{
${ }^{13}$ Certain factors, such as oil or gold prices, could be included as either global or sectoral factors. The sensitivity analysis examines using different definitions and finds that it has no effect on the key results.

${ }^{14} \mathrm{We}$ include only five countries due to data limitations. More specifically, the direct investment data are not available for other large economies, such as Spain or Italy (after 1994).
} 
In each of our estimates, we also include at least one global factor. In our simplest regressions, the only global factor is world stock returns. In order to minimize multicollinearity, we use the residual world stock return after controlling for returns in the five largest countries $c .{ }^{15} \mathrm{We}$ also estimate a series of regressions with a broader set of global controls. The four additional global factors are: global interest rates, oil prices, gold prices, and commodity prices. All factors are calculated as changes or returns for the relevant price. Global interest rates are calculated as the principal component from overnight discount rates in the United States, the United Kingdom, and Japan. ${ }^{16}$ Oil prices are the current dollar prices per barrel for Brent oil, calculated as freight on board. Gold prices are the prices of gold bullion in dollars per ounce on the London Bullion Market. Gold prices are included as a global factor in order to capture any changes in global risk aversion. Commodity prices are an index calculated by the Economist based on U.S. dollar prices of a large basket of commodities.

Many of the base estimates control for sectoral factors as well as global factors. The main sectoral factors on which we focus are weekly returns based on the Morgan Stanley Capital International (MSCI) industrial sector indices. These indices are based on U.S. dollar stock returns in 45 countries, with weights based on country production in the given sector. We use the $36 \mathrm{MSCI}$ indices available for the relevant period to create 14 sectoral factors: automobiles, chemicals, consumer goods, electronics, energy, forest products and paper, industrial components, financial, leisure and tourism, merchandising, metals, telecommunications, textiles and apparel, and transportation. ${ }^{17}$

For the second-stage regressions, when we estimate the cross-country factor loadings as a function of specific bilateral linkages in equation (2), we construct a data set from several sources. The GDP data used as a denominator for many of these statistics is taken from the World Bank's World Development Indicators (and reported in U.S. dollars). The trade data used to calculate Import Demand ${ }_{i}^{c}$ and Trade Competition ${ }_{i}^{c}$ are from the Statistics Canada database, accessed through the Worldview Trade Analyzer service. This database reports bilateral trade flows between

\footnotetext{
${ }^{15}$ More specifically, we estimate a regression of global stock market returns (calculated based on the Datastream world index in U.S. dollars) on stock returns in the five largest economies $c$. Then we use the estimated coefficients over the given time period to calculate the residual global stock market return.

${ }^{16}$ Overnight rates for other large European countries, such as Germany or France, are not included in calculating the principal component, due to the break in their series in 1999 with the adoption of the euro.

${ }^{17}$ See Appendix A of Forbes and Chinn (2003) for further details on the creation of these 14 indices. As discussed in the sensitivity analysis, we also include each of the 36 MSCI sectoral indices as independent sectoral factors. Including such a large number of factors, however, severely limits the degrees of freedom for the analysis. Moreover, some of these more disaggregated factors are even more highly correlated with the global factors and/or individual country factors.
}

most countries in the world by four-digit SITC codes. ${ }^{18}$ More specifically, Import Demand ${ }_{i}^{c}$ is measured as imports into country $c$ from country $i$ as a share of country $i$ 's GDP:

$$
\operatorname{Import~Demand}_{i}^{c}=\frac{\operatorname{Imp}_{i}^{c}}{G D P_{i}},
$$

where $\operatorname{Imp} p_{i}^{c}$ is total imports into large country $c$ from country $i$, and $G D P_{i}$ is the GDP for country $i$. All variables are measured in U.S. dollars.

The second cross-country linkage variable included in equation (2), Trade Competition ${ }_{i}^{c}$, is a weighted sum of products of two factors. The first is exports from country $c$ in a given industry as a share of world exports in that industry. This factor captures how important exports from country $c$ are to the industry, and therefore the potential impact of shocks to country $c$ on the industry as a whole. The second factor is total exports from country $i$ in the same industry, as a share of country $i$ 's GDP. This factor captures the importance of each industry to country $i$. Finally, the products of these two factors are summed across all fourdigit industries for each pair of countries $i$ and $c$, and then weighted by the maximum calculated value (and multiplied by 100). This creates an index that can take values from 0 to 100. In other words, Trade Competition ${ }_{i}^{c}$ is calculated as

\section{Trade Competition ${ }_{i}^{c}$}

$$
=\frac{100}{\operatorname{Max}_{\text {TradeCompetition }}} \sum_{k}\left(\frac{\operatorname{Exp}_{W, k}^{c}}{\operatorname{Exp}_{W, k}^{W}} \frac{\operatorname{Exp}_{W, k}^{i}}{G D P_{i}}\right),
$$

where $\operatorname{Exp}_{W, k}^{c}$ is exports from large country $c$ to every other country in the world $(W)$ in industry $k ; \operatorname{Exp}_{W, k}^{W}$ is exports from every country in the world to every other country in the world (that is, total global exports) in industry $k ; \operatorname{Exp}_{W, k}^{i}$ is exports from country $i$ to every other country in the world in industry $k ; G D P_{i}$ is the GDP for country $i$; and Max $_{\text {TradeCompetition }}$ is the maximum value of the product in parentheses for every country pair in the sample. All variables continue to be measured in U.S. dollars. The $k$ industries are approximately 1000 four-digit SITC groups.

It is worth noting that the trade competition variable in equation (4) is a substantial improvement on that used in earlier work. ${ }^{19}$ Previous studies generally attempted to measure trade competition by examining aggregate trade flows to common markets. This measure often misclassified countries as direct competitors if the two countries were highly dependent on a common market, even if the two countries did not directly compete in any specific industries. For example, if a high proportion of Saudi Arabia's oil and of

\footnotetext{
18 The Worldview online database has the advantage of reporting more up-to-date information and a longer time series. See http://www. trademeasures.com/MSIEIndex.html for more information.

${ }^{19}$ Forbes (2002) is the only other paper (to the best of our knowledge) to calculate a trade competition variable based on four-digit SITC information.
} 
Brazil's coffee goes to the same third market, Saudi Arabia and Brazil would have been classified as direct competitors. By focusing on trade in specific industries, instead of aggregate trade flows to common countries, this paper's statistics should provide more accurate measures of trade competition.

The data used to calculate the third cross-country linkage variable included in equation (2), Bank Lending ${ }_{i}^{c}$, are based on lending data reported by the Bank of International Settlements (BIS). Bank Lending ${ }_{i}^{c}$ is measured as the total stock of bank lending from country $c$ in country $i$ as a share of country $i$ 's GDP. ${ }^{20}$ The data used to calculate the final global linkage variable, Foreign Investment ${ }_{i}^{c}$, is based on the OECD's International Direct Investment Statistics Yearbook (2001). ${ }^{21}$ Foreign Investment ${ }_{i}^{c}$ is measured as the total stock of foreign investment from country $c$ in country $i$ as a share of country $i$ 's GDP. These two global linkage variables can be written as

$$
\begin{aligned}
& \text { Bank Lending }{ }_{i}^{c}=\frac{\text { Lending }_{i}^{c}}{G D P_{i}}, \\
& \text { Foreign Investment } t_{i}^{c}=\frac{\text { Investment }_{i}^{c}}{G D P_{i}},
\end{aligned}
$$

where Lending ${ }_{i}^{c}$ is total bank lending from large country $c$ to country $i$; Investment $t_{i}^{c}$ is total foreign direct investment from large country $c$ to country $i$; and $G D P_{i}$ is the GDP of country $i$. All variables are measured in U.S. dollars. ${ }^{22}$ It is worth noting that Foreign Investment does not include "portfolio investment" and smaller investment flows across countries. $^{23}$

Combining the information for these four bilateral linkage variables defined in equations (3) through (6) with the weekly stock and bond return information yields a data set with information on 38 countries $i$ and 5 large countries $c$ from 1985 through 2000. Information is not available for the full period on many countries - often because stock or bond markets did not exist at the start of the period. Appendix A reports the full sample of countries, by region, as well as the years for which data are available for the factor model

\footnotetext{
${ }^{20}$ This is the consolidated international claims of BIS reporting banks within country $c$ into country $i$.

${ }^{21}$ This is the total outward direct investment position reported by each OECD country, representing investment into all other countries.

${ }^{22}$ Direct investment data are reported in local-currencies, which are then converted to U.S. dollars using end-of-period exchange rates.

${ }^{23}$ More specifically, direct investment is the "lasting interest of a resident entity in one economy (direct investor) in an entity resident in another economy (direct investment enterprise)" (OECD, 2001). Direct investment is generally defined as when a direct investor, who is a resident in another economy, owns $10 \%$ or more of the ordinary shares, voting power, or equivalent, of a direct investment enterprise. Bank lending is generally classified as portfolio investment and not as direct investment. Also, the foreign investment data are based on statistics reported by each national government. Therefore, although the OECD attempts to ensure the same definitions and standards across countries, different reporting standards persist.
}

Table 1.-Means and Standard Deviations for Bilateral LINKAGE VARIABLES ${ }^{\mathrm{a}}$

\begin{tabular}{lccccc}
\hline \hline \multirow{2}{*}{ Variable } & Full Period & & \multicolumn{3}{c}{ Subperiods } \\
\cline { 2 - 5 } \cline { 5 - 6 } \cline { 5 - 6 } & $1986-2000$ & & $1986-1990$ & $1991-1995$ & $1996-2000$ \\
\hline Import Demand & 2.88 & & 2.78 & 2.69 & 3.17 \\
& $(4.35)$ & & $(4.18)$ & $(4.00)$ & $(4.82)$ \\
Trade Competition & 13.15 & & 12.38 & 12.85 & 14.19 \\
& $(13.12)$ & & $(13.52)$ & $(12.91)$ & $(12.89)$ \\
Bank Lending & 5.12 & & 7.03 & 4.76 & 3.91 \\
& $(15.98)$ & & $(22.99)$ & $(15.79)$ & $(6.49)$ \\
Foreign Investment & 2.36 & & 1.96 & 2.18 & 2.93 \\
& $(3.78)$ & & $(3.04)$ & $(3.33)$ & $(4.68)$ \\
\hline
\end{tabular}

a Means are listed with corresponding standard deviations in parentheses.

Table 2.-Correlations between Bilateral Linkage Variables: 1986-2000

\begin{tabular}{lcccc}
\hline \hline \multicolumn{1}{c}{ Variable } & $\begin{array}{c}\text { Import } \\
\text { Demand }\end{array}$ & $\begin{array}{c}\text { Trade } \\
\text { Competition }\end{array}$ & $\begin{array}{c}\text { Bank } \\
\text { Lending }\end{array}$ & $\begin{array}{c}\text { Foreign } \\
\text { Investment }\end{array}$ \\
\hline $\begin{array}{l}\text { Import Demand } \\
\text { Trade Competition }\end{array}$ & 1.00 & & & \\
Bank Lending & 0.66 & 1.00 & & \\
Foreign Investment & 0.22 & 0.51 & 1.00 & \\
\hline
\end{tabular}

regressions for different asset markets. The correlation matrix for each of the factors shows that, as expected, there is a high correlation between several of the sectoral indices and the Japanese and U.S. cross-country factors. ${ }^{24}$ As a result, it may be difficult to isolate the direct impact of shocks to the United States and Japan on other countries from the impact of shocks to the United States and Japan working through these sectors. On a more positive note, the correlations between the global factors and the crosscountry factors are extremely low, suggesting that multicollinearity between the global and cross-country factors should not affect estimates of the cross-country factor loadings.

As discussed in sections I and II, many of the bilateral linkage variables used in the second-stage regressions and defined in equations (3) through (6) have not been widely used (and have never been used simultaneously) in previous work. Therefore, tables 1 through 3 provide additional information on these four variables. Table 1 reports means and standard deviations for the full period of time, as well as for several different subperiods. Most of the trade and foreign investment linkages increased over the period from 1986 through 2000. Bank lending, however, fell substantially between the period 1986-1990 and the period 19911995. This undoubtedly reflects decreased bank lending to emerging markets after the 1980s debt crisis. Despite this decline, average bank lending from the five larger countries to smaller countries (as a share of smaller-country GDP) is still greater than direct investment between the same sets of countries, although this gap has been closing over time. Table 2 reports correlations between the four bilateral

\footnotetext{
${ }^{24}$ The correlation matrix is available as appendix B in Forbes and Chinn (2003).
} 
Table 3.--Selection of Bilateral Linkage Variables with Japan or the United States

\begin{tabular}{|c|c|c|c|c|c|c|c|c|}
\hline \multirow[b]{2}{*}{ Country $i$} & \multicolumn{4}{|c|}{1985} & \multicolumn{4}{|c|}{2000} \\
\hline & $\begin{array}{c}\text { Import } \\
\text { Demand }^{\mathrm{a}}\end{array}$ & $\begin{array}{l}\text { Trade } \\
\text { Comp. }\end{array}$ & $\begin{array}{c}\text { Bank } \\
\text { Lending }^{\mathrm{c}}\end{array}$ & $\begin{array}{l}\text { Foreign } \\
\text { Invest. }^{\mathrm{d}}\end{array}$ & $\begin{array}{c}\text { Import } \\
\text { Demand }\end{array}$ & $\begin{array}{l}\text { Trade } \\
\text { Comp. }^{\mathrm{b}}\end{array}$ & $\begin{array}{c}\text { Bank } \\
\text { Lending }\end{array}$ & $\begin{array}{l}\text { Foreign } \\
\text { Invest. }^{\mathrm{d}}\end{array}$ \\
\hline \multicolumn{9}{|c|}{ Bilateral Linkages with Japan } \\
\hline Australia & 3.8 & 1.8 & 4.8 & 2.1 & 3.0 & 3.9 & 2.4 & 2.0 \\
\hline Brazil & 0.7 & 4.5 & 4.8 & 2.1 & 0.5 & 3.1 & 0.5 & 0.7 \\
\hline Canada & 1.3 & 21.9 & & 0.5 & 1.0 & 23.7 & 1.8 & 0.9 \\
\hline China & 1.9 & 1.4 & 1.0 & 0.1 & 4.1 & 8.9 & 1.0 & 0.8 \\
\hline India & 0.5 & 0.8 & 0.4 & 0.0 & 0.6 & 1.7 & 0.5 & 0.3 \\
\hline Indonesia & 11.1 & 1.4 & 5.9 & 9.5 & 10.5 & 8.0 & 6.7 & 3.1 \\
\hline Korea & 5.0 & 18.1 & 10.4 & 1.8 & 4.6 & 17.3 & 2.2 & 0.9 \\
\hline Malaysia & 12.0 & 6.3 & 15.4 & 3.5 & 14.7 & 36.4 & 6.2 & 4.5 \\
\hline Mexico & 1.0 & 3.8 & 7.0 & 0.7 & 0.2 & 17.0 & 0.4 & 0.4 \\
\hline Thailand & 2.6 & 5.7 & 7.8 & 2.0 & 8.3 & 20.2 & 8.0 & 3.9 \\
\hline \multicolumn{9}{|c|}{ Bilateral Linkages with United States } \\
\hline Australia & 1.3 & 14.3 & 3.0 & 5.1 & 1.5 & 13.5 & 1.7 & 9.1 \\
\hline Brazil & 3.5 & 8.2 & 9.6 & 4.0 & 2.5 & 6.4 & 2.4 & 6.0 \\
\hline Canada & 21.2 & 21.0 & & 13.4 & 37.2 & 30.4 & 2.0 & 18.4 \\
\hline China & 0.8 & 3.3 & 0.2 & 0.1 & 5.5 & 14.7 & 0.1 & 0.9 \\
\hline India & 0.9 & 2.1 & 0.4 & 0.2 & 2.5 & 5.7 & 0.5 & 0.3 \\
\hline Indonesia & 5.5 & 3.5 & 3.0 & 5.1 & 6.1 & 16.9 & 2.1 & 7.6 \\
\hline Korea & 12.4 & 11.0 & 8.8 & 0.8 & 8.8 & 20.0 & 1.3 & 2.0 \\
\hline Malaysia & 7.0 & 11.1 & 3.3 & 3.6 & 24.4 & 59.5 & 1.2 & 6.7 \\
\hline Mexico & 9.0 & 5.0 & 12.8 & 2.8 & 26.4 & 21.0 & 2.6 & 6.1 \\
\hline Thailand & 3.9 & 16.8 & 4.3 & 2.8 & 12.9 & 36.6 & 0.8 & 5.8 \\
\hline
\end{tabular}

See section IV for additional information on variable definitions. All variables expressed in percent.

a Import Demand is the ratio of imports from country $i$ to country $c$ as a share of country $i$ 's GDP. See equation (3).

Trade Competition is an index from 1 to 100 capturing the importance of trade competition between countries $i$ and $c$ relative to country $i$ 's GDP, based on four-digit SITC information. See equation (4).

${ }^{c}$ Bank Lending is the total stock of bank lending from country $c$ in country $i$ as a share of country $i$ 's GDP. See equation (5).

d Foreign Investment is the total stock of foreign investment from country $c$ in country $i$ as a share of country $i$ 's GDP. See equation (6).

linkage variables for the full period. The two trade variables (Import Demand and Trade Competition) are the most highly correlated-with an average correlation of $66 \%$ over the full period from 1986 to 2000. Foreign Investment also tends to be highly correlated with the trade variables. Bank Lending tends to be the least correlated with the other variables.

To better understand how these bilateral linkages fluctuate across different countries and periods, Table 3 reports a selection of values for the United States and Japan (two of the larger countries indexed by $c$ ) and a selection of 10 smaller countries indexed by $i$ in 1985 and 2000. Most of the patterns are not surprising. For example, all four of the bilateral linkage variables are substantially lower for economies traditionally considered to be less integrated with the global economy, such as China and India. Import Demand in Mexico and in Canada with respect to the United States is very large and increased substantially between 1985 and 2000. Import Demand in many smaller Asian countries is fairly large with respect to both Japan and the United States. For some of these economies, such as Malaysia and Thailand, reliance on imports into the U.S. increased substantially between 1985 and 2000, so that the U.S. is currently a more important export market than nearby Japan. Countries that produce more high-tech goods, such as Korea and Malaysia, tend to have higher values of Trade Competition with the U.S. and Japan. Bank Lending from both Japan and the United States has decreased between 1985 and 2000, as has Foreign Investment from Japan. In sharp contrast, many countries' reliance on Foreign Investment from the U.S. has increased over time.

\section{Estimation Results: Average Stock Market Linkages from 1986 to 2000}

\section{A. Factor Model of Stock Returns}

To begin, we use the data set described in section IV to estimate the simplest form of the factor model in equation (1) - with controls for the five cross-country factors and one global factor (the world stock market return). We focus on the full sample period (1986-2000) for stock markets expressed in U.S. dollars. ${ }^{25}$ Table 4 reports the corresponding $R^{2}$ 's for the full regressions, and the coefficient estimates and standard errors for each of the five cross-country factor loadings (the $\beta_{i}^{c}$ 's).

The size and significance of the estimated cross-country factor loadings vary by region, with the major economy (or economies) in each region usually the most important for nearby markets. For example, the U.S. factor is most often positive and significant in the Americas. Many of the crosscountry factors follow intuitive patterns based on cultural similarities or colonial origin. For example, the U.K. factor

\footnotetext{
25 To simplify the discussion of results, we focus on U.S. dollar estimates. See Forbes and Chinn (2003) for local-currency estimates. The currency choice does not change the key results.
} 
Table 4.-Estimated Cross-Country Factor Loadings: U.S. DOLLAR STOCK RETURNS

\begin{tabular}{|c|c|c|c|c|c|c|}
\hline Country $i$ & $R^{2}$ & France & Germany & Japan & U.K. & U.S. \\
\hline \multicolumn{7}{|c|}{ Americas } \\
\hline Argentina & 0.03 & $0.51^{* *}$ & -0.07 & 0.02 & $-0.43^{*}$ & $0.55^{* *}$ \\
\hline Brazil & 0.21 & 0.12 & 0.09 & 0.13 & $0.29 *$ & $0.60 * *$ \\
\hline Canada & 0.52 & $0.08 * *$ & 0.01 & 0.01 & $0.14 * *$ & $0.61 * *$ \\
\hline Chile & 0.10 & 0.03 & 0.01 & -0.02 & $0.21 * *$ & $0.27 * *$ \\
\hline Colombia & 0.04 & -0.09 & $0.21 *$ & 0.02 & $0.23^{*}$ & -0.03 \\
\hline Mexico & 0.15 & 0.05 & 0.19 & 0.10 & 0.12 & $0.63^{* *}$ \\
\hline Venezuela & 0.05 & 0.41 & -0.21 & -0.03 & $0.62 * *$ & -0.13 \\
\hline \multicolumn{7}{|c|}{ Asia } \\
\hline Australia & 0.26 & 0.01 & $0.11 * *$ & $0.07 * *$ & $0.45^{* *}$ & 0.09 \\
\hline China & 0.10 & $-0.33^{*}$ & $0.42 * *$ & $0.41 * *$ & 0.22 & 0.09 \\
\hline Hong Kong & 0.19 & 0.07 & $0.27 * *$ & 0.07 & $0.31 * *$ & $0.18 * *$ \\
\hline India & 0.03 & $0.28 * *$ & 0.18 & -0.06 & -0.14 & -0.10 \\
\hline Indonesia & 0.02 & 0.05 & 0.13 & 0.23 & $0.53 * *$ & -0.43 \\
\hline Korea & 0.08 & $0.23 *$ & -0.01 & $0.29 * *$ & 0.08 & $0.30 * *$ \\
\hline Malaysia & 0.12 & -0.07 & $0.23 * *$ & $0.21 * *$ & $0.29 * *$ & $0.17^{*}$ \\
\hline \multicolumn{7}{|l|}{ New } \\
\hline Zealand & 0.18 & 0.00 & 0.10 & $0.15 * *$ & $0.30 * *$ & $0.14 * *$ \\
\hline Philippines & 0.11 & 0.07 & $0.26 * *$ & $0.10 *$ & 0.12 & $0.23^{* *}$ \\
\hline Singapore & 0.28 & -0.03 & $0.18 * *$ & $.19 * *$ & $0.38 * *$ & $0.23 * *$ \\
\hline Thailand & 0.14 & 0.08 & $0.35 * *$ & $0.24 * *$ & $0.22 * *$ & 0.15 \\
\hline \multicolumn{7}{|c|}{ Europe } \\
\hline Austria & 0.40 & $0.12 * *$ & 0.58 & $0.11 * *$ & 0.03 & $-0.15^{* *}$ \\
\hline Belgium & 0.45 & $0.20 * *$ & $0.35 * *$ & $0.06 * *$ & $0.12 * *$ & $-0.07^{*}$ \\
\hline Denmark & 0.31 & $0.09 * *$ & $0.37 * *$ & $0.05^{* *}$ & $0.17 * *$ & $-0.09 * *$ \\
\hline Finland & 0.31 & $0.18 * *$ & $0.35^{* *}$ & 0.00 & $0.30 * *$ & $0.37 * *$ \\
\hline Greece & 0.15 & $0.21 * *$ & $0.43 * *$ & $0.18 * *$ & 0.01 & -0.02 \\
\hline Hungary & 0.21 & 0.18 & $0.42 * *$ & 0.00 & $0.36^{* * *}$ & 0.13 \\
\hline Iceland & 0.08 & -0.01 & $0.17 * *$ & -0.05 & 0.08 & -0.04 \\
\hline Ireland & 0.43 & 0.06 & $0.19 * *$ & $0.05^{*}$ & $0.57 * *$ & 0.04 \\
\hline Italy & 0.32 & $0.34 * *$ & $0.29 * *$ & 0.03 & $0.17 * *$ & 0.01 \\
\hline Netherlands & 0.68 & $0.09 * *$ & $0.37 * *$ & $0.05 * *$ & $0.22 * *$ & $0.12 * *$ \\
\hline Norway & 0.31 & 0.01 & $0.40 * *$ & 0.03 & $0.33^{* * *}$ & $0.11 * *$ \\
\hline Poland & 0.16 & 0.13 & $0.67 * *$ & -0.01 & 0.09 & $0.28^{*}$ \\
\hline Portugal & 0.38 & $0.27 * *$ & $0.41 * *$ & 0.04 & 0.04 & -0.07 \\
\hline Spain & 0.49 & $0.25 * *$ & $0.35 * *$ & $0.07 * *$ & $0.20 * *$ & $0.09^{* *}$ \\
\hline Sweden & 0.42 & $0.15^{* *}$ & $0.43 * *$ & 0.04 & $0.23 * *$ & $0.22 * *$ \\
\hline Switzerland & 0.60 & $0.13^{* *}$ & $0.44 * *$ & $0.08 * *$ & $0.21 * *$ & -0.03 \\
\hline
\end{tabular}

Middle East and Africa

$\begin{array}{lrllrll}\text { Israel } & 0.19 & 0.30 * * & 0.06 & -0.06 & 0.05 & 0.44 * * \\ \text { South Africa } & 0.24 & 0.17 * * & 0.35^{* *} & 0.02 & 0.27 * * & 0.04 \\ \text { Turkey } & 0.03 & -0.09 & 0.47 * * & 0.14 & 0.15 & 0.05\end{array}$

Estimates of cross-country betas from equation (1) with control variables for cross-country factors an global market residual. No controls for the sectoral factors or additional global factors. ** and * mean significant at the 5\% and $10 \%$ level, respectively.

is large and significant in Australia, Hong Kong, and South Africa, and the U.S. factor is large and significant in Israel. The magnitude of the estimates suggests that the impact of stock market movements in large economies on small economies can be large. For example, the coefficient 0.55 on the U.S. factor for Argentina suggests that a $10 \%$ return in the U.S. stock market is associated with a $5.5 \%$ return in the Argentine market.

Next, in order to control for sectoral shocks and a broader set of global shocks, we reestimate equation (1), including the additional 4 global factors and 14 sectoral factors discussed in section IV. Figure 1 shows results from $F$-tests of the joint significance of the global, sectoral, and crosscountry factors. Shaded bars indicate that the relevant group of factors are jointly significant (at the $10 \%$ level) for each country $i$. The global, sectoral, and cross-country factors are each often jointly significant, although the global factors are less often significant than the other two sets of factors. For example, out of the 37 regressions, the global factors are jointly significant in 12 cases; the sectoral factors are jointly significant in 29 cases; and the cross-country factors are jointly significant in 32 cases. The relative importance of the three different sets of factors fluctuates across regions. For example, the global factors are often significant in the Americas, but rarely in Asia.

It is also worth noting that although the cross-country factors tend to be jointly significant for most countries, the U.S. and Japanese factors are less often individually significant than in table 4 (although most of the other estimates are similar). This is caused by the multicollinearity between the Japanese and U.S. factors with the sectoral factors, as discussed in section IV. In other words, the sectoral factors capture much of the direct cross-country effect of shocks to the Japanese and U.S. markets on other countries. This suggests that there are advantages and disadvantages to including the sectoral factors when estimating cross-country linkages in equation (1). On one hand, theory suggests that in order to obtain unbiased estimates of cross-country factor loadings, it is necessary to control for sectoral shocks. On the other hand, the high correlation between the sectoral and cross-country factors could cause much of the direct impact of shocks to large countries on other countries to be captured in estimates of the sectoral loadings. Therefore, in the remainder of this paper, we estimate the factor model both with and without the full set of factors.

\section{B. Decomposition of Cross-Country Linkages}

Before decomposing the estimated cross-country factor loadings into specific bilateral linkages, we examine the time series characteristics of the variables to test for nonstationarity. There is a strong likelihood that some of the variables have drifted upward over time as global integration has increased. These unit root tests and their outcomes are discussed in detail in appendix B. The results suggest that all of the variables are stationary except Foreign Investment. The evidence of nonstationarity in Foreign Investment is not surprising, given the increase in foreign direct investment documented in table 1 . Consequently, the subsequent analysis uses the first difference (instead of the level) of foreign direct investment in order to estimate equation (2). ${ }^{26}$ This series of results also suggests that

\footnotetext{
26 The sensitivity analysis also examines the effect of using levels instead of first differences for Foreign Investment. The key results do not change.
} 
Figure 1.-Joint Significance of Different Factor Groups-Stock Returns

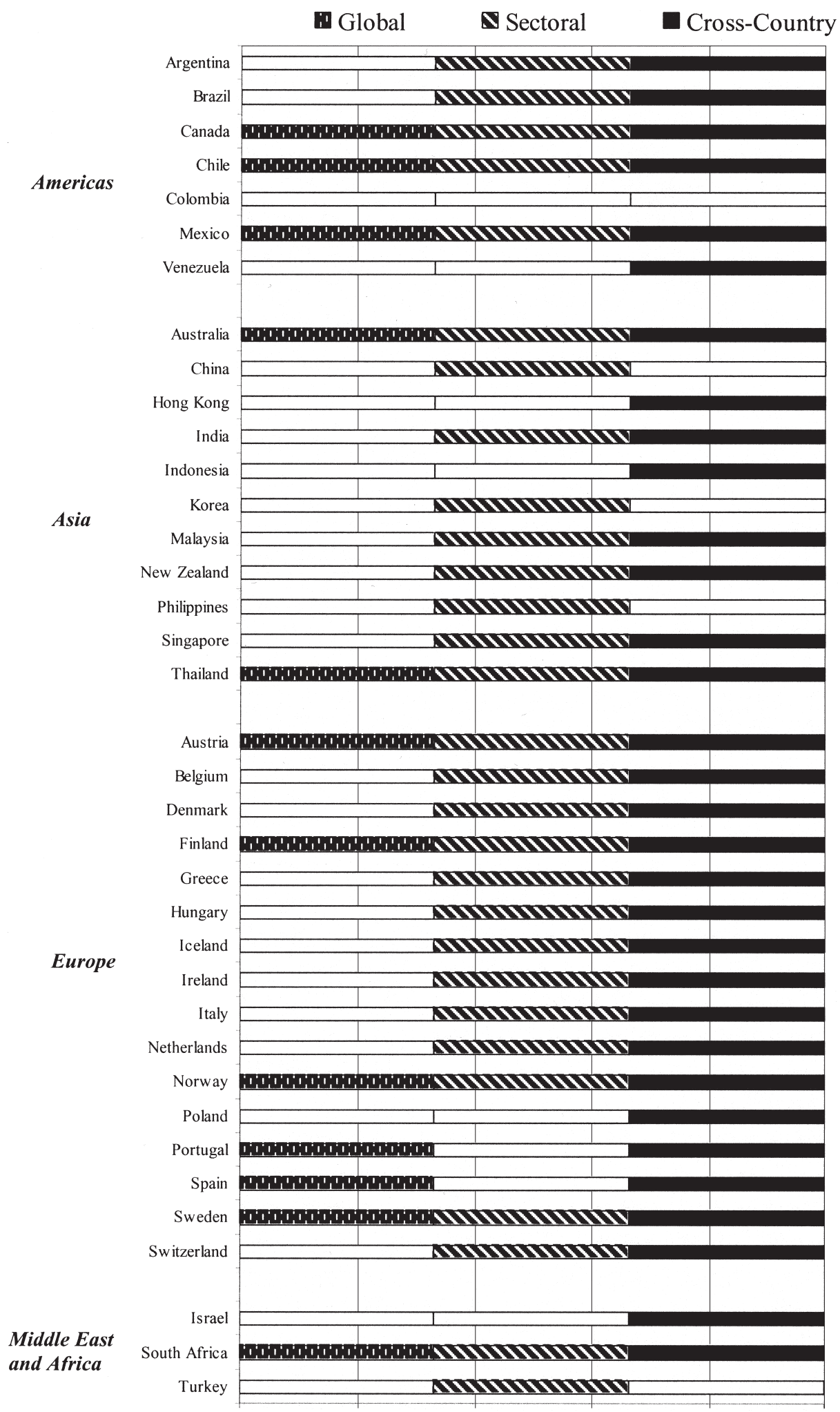


Table 5.-Bilateral LinKage Regressions for Stock Markets

\begin{tabular}{lccccccc}
\hline \hline \multicolumn{1}{c}{ Factors $^{\mathrm{a}}$} & $N$ & $R^{2}$ & $\begin{array}{c}\text { Import } \\
\text { Demand }\end{array}$ & $\begin{array}{c}\text { Trade } \\
\text { Comp. }\end{array}$ & $\begin{array}{c}\text { Bank } \\
\text { Lending }\end{array}$ & $\begin{array}{c}\text { Foreign } \\
\text { Invest. }\end{array}$ & $\begin{array}{c}\text { Capital } \\
\text { Controls }\end{array}$ \\
\hline \multirow{6}{*}{ World market } & 161 & 0.12 & $1.85^{* *}$ & -0.23 & 0.09 & -3.48 & 0.00 \\
& & & $(0.44)$ & $(0.17)$ & $(0.11)$ & $(3.89)$ & $(0.01)$ \\
Full set & 161 & 0.05 & $1.31^{* *}$ & $-0.44^{*}$ & 0.28 & 6.47 & 0.01 \\
& & & $(0.56)$ & $(0.23)$ & $(0.21)$ & $(4.98)$ & $(0.02)$
\end{tabular}

Early Subperiod: 1986-1990

$\begin{array}{lccccccc}\text { World market } & 60 & 0.04 & 0.35 & 0.06 & 0.03 & -9.43 & 0.03 \\ & & & (0.44) & (0.23) & (0.10) & (8.66) & (0.02) \\ \text { Full set } & 60 & 0.14 & -6.70 * * & 2.21 * * & -0.75^{*} & 27.29 & -0.07 \\ & & & (1.29) & (0.72) & (0.40) & (38.12) & (0.05)\end{array}$

Middle Subperiod: 1991-1995

$\begin{array}{lccccccc}\text { World market } & 104 & 0.01 & 0.15 & 0.05 & -0.21 & -8.99 & 0.02 \\ & & & (1.07) & (0.28) & (0.15) & (12.12) & (0.02) \\ \text { Full set } & 104 & 0.02 & -2.59 & 0.23 & 0.28 & 21.63 & 0.00 \\ & & & (1.93) & (0.64) & (0.24) & (19.22) & (0.07)\end{array}$

Late Subperiod: 1996-2000

World market $149 \quad 0.22 \quad 2.03 * * \quad-0.49 * * \quad 0.66 * * \quad-3.28 * \quad-0.00$

$\begin{array}{lllll}(0.30) & (0.15) & (0.28) & (1.70) & (0.01)\end{array}$

Full set $\quad \begin{array}{lllllll}149 & 0.19 & 2.26 * * & -0.89 * * & 1.40 * * & 1.88 & 0.02\end{array}$

$\begin{array}{lllll}(0.62) & (0.22) & (0.37) & (2.89) & (0.02)\end{array}$

Coefficient estimates of equation (2) for U.S. dollar stock market returns. Standard errors in parentheses. ** and * mean significant at the $5 \%$ and $10 \%$ level, respectively.

a "World market" is the residual of the global market return. "Full set" is the full set of 5 global factor (including the global market return) as well as the 14 sectoral factors.

inference based on OLS estimates is accurate and it is not necessary to use panel-cointegration methods. ${ }^{27}$

Next, we use the estimated cross-country factor loadings to estimate equation (2) and decompose these cross-country linkages into specific bilateral linkages. Table 5 reports coefficient estimates based on U.S. dollar stock returns for the full period from 1986 to $2000 .^{28}$ It reports results based on the simplest set of controls (only the world market return) in equation (1), as well as with the full set of global and sectoral controls. As discussed in section II, there is an extensive literature examining how integration with the global economy and capital controls can affect stock market returns and cross-market comovement. Therefore, we also include Chinn and Ito's (2002) measure of capital account openness in each country $i{ }^{29}$ This statistic is calculated as a standardized principal component of four IMF dummy variables measuring different types of external account restrictions, with an adjustment for the length of time that the

\footnotetext{
${ }^{27}$ All estimates are also adjusted for heteroskedasticity and serial correlation.

${ }^{28}$ All variables are averages based on annual values for each year available from 1986 to 2000 . Stock variables are measured at the start of each year (or end of the previous year).

${ }^{29}$ Excluding this variable has little effect on the results. We assume that financial markets in each of the large countries $c$ have limited capital account restrictions and are fairly well integrated with global financial markets.
}

capital controls were in place. ${ }^{30} \mathrm{~A}$ higher value indicates greater capital account openness.

The most consistent finding at the top of table 5 is that the coefficient on Import Demand is positive and highly significant (at the 5\% level). This suggests that on average between 1986 and 2000, direct trade may have been the most important bilateral linkage determining how shocks to the world's largest economies affected other stock markets. The estimated coefficients on Trade Competition, Bank Lending, and Foreign Investment are never significant at the $5 \%$ level. The explanatory power of these regressions is fairly low, with only $5 \%-12 \%$ of the variance explained. ${ }^{31}$

As an extension to these results, instead of using variables averaged over the entire 15-year period from 1986 to 2000, we use estimated annual cross-country factor loadings to estimate panel regressions. We also include period dummy variables for each year. Despite the substantial increase in the number of observations, the regressions have an even lower explanatory power than those based on the periodaveraged data. The only consistently significant estimate continues to be the positive coefficient on Import Demand.

\section{Estimation Results: Changes in Global Linkages in Stock Markets over Time}

One problem with the results reported in section $\mathrm{V}$-which could explain the low explanatory power of the models - is that the specification imposes the constraint that each of the coefficients and their underlying relationships are constant between 1986 and 2000. Global linkages and the determinants of stock market returns, however, may have changed over this sample period. As discussed in section II, trends in the TMT sector could have changed the importance of sectoral factors relative to other factors in the late 1990s. Or, as also discussed in section II, many emerging markets have only recently become integrated with global financial markets, causing significant changes in their relationships with other countries. Therefore, this section examines if the average results for the full sample period reported above mask important changes over time.

\section{A. Factor Model of Stock Returns}

To test if the importance of the global, sectoral, and cross-country factors has changed between 1986 and 2000, we divide the full sample period into three subperiods of equal length: 1986-1990, 1991-1995, and 1996-2000. Then we estimate equation (1) for each 5-year period with the different sets of controls. Two key results emerge from these regressions. First, the sectoral factors appear to be more

\footnotetext{
30 The creation of this statistic is described in more detail in Appendix D of Forbes and Chinn (2003). The sensitivity analysis also reports results using other measures of capital controls. These other measures, however, are only available for a much more limited selection of countries.

${ }^{31}$ Many models attempting to explain stock market movements have a low degree of explanatory power, because financial market prices are affected by a wide variety of hard-to-measure influences.
} 
important in the later period 1996-2000 than in early periods, especially in Asia. This could partially reflect the TMT bubble discussed in section II. Second, the U.S. factor is more often significant and the Japanese factor is less often significant between 1996 and 2000 than in the earlier periods. These changes undoubtedly reflect the stronger growth in the U.S. economy over the latter half of the 1990 s and its increased importance as an export market for countries around the world.

\section{B. Decomposition of Cross-Country Linkages}

Next, we use the estimated cross-country factor loadings from section VI A to estimate the importance of the four real and financial linkage variables during the different 5-year periods between 1986 and 2000. The bottom of table 5 reports results. ${ }^{32}$ The coefficient estimates indicate that there were substantial changes in the importance of the bilateral linkage variables in the different subperiods. In the earlier two periods (1986-1990 and 1991-1995), most of the coefficient estimates are insignificant, and of the few that are significant, none are robust across alternative specifications. Not only does the coefficient significance vary across specifications, but even the estimated signs show a remarkable lack of stability. Not surprisingly, the proportion of the variance explained by the models in both of these periods is very low.

Estimates during the later period 1996-2000, however, reflect very different patterns. There is a dramatic increase in the model's explanatory power, with the proportion of the variance explained by the model increasing to $19 \%-22 \%$. There is also a substantial increase in the consistency of most estimates across the different specifications. The coefficients on Import Demand are always positive and significant (at the 5\% level). The coefficients on Bank Lending are also positive and significant, and the coefficients on Trade Competition are negative and significant, although both of these results are less robust in the annual-panel estimates (unreported). Moreover, the sensitivity analysis in section VIII shows that these estimates are also not as robust to alternate samples, definitions, and specifications as those for Import Demand. The estimates for Foreign Investment are the only ones that continue to be insignificant (at the 5\% level) with fluctuating signs.

These results indicate that in the latter half of the 1990s, bilateral linkages became more important determinants of how shocks to large financial markets are transmitted to smaller countries around the world. In particular, direct trade appears to be the most consistently significant bilateral linkage. One surprising result is that foreign investment, despite its rapid growth in recent years, does not appear to

\footnotetext{
${ }^{32}$ Local currency estimates, panel estimates based on annual data, and estimates without controls for capital account restrictions are not reported due to space constraints. Each of these sets of results is available in tables 6 and 7 of Forbes and Chinn (2003). The central results are identical to those discussed above.
}

be a significant determinant of bilateral linkages in financial markets. This could partially be caused by noise in the bilateral data on foreign investment (as discussed in section IV).

The coefficient estimates also suggest not only that bilateral linkages other than foreign direct investment are significant determinants of stock market comovements, but that the magnitude of this impact can be large. For example, consider Chile, which is in the process of finalizing a free-trade agreement with the United States. From 1996 to 2000, Import Demand for Chile with respect to the United States was $4.0 \%$, and the estimated U.S. cross-country factor loading was $0.27 .^{33}$ Then assume that Chile's Import Demand variable increased to $25.1 \%$, which is the value for Mexico with respect to the United States from 1996 to 2000. Holding everything else constant, the U.S. factor loading for Chile would be predicted to increase to $0.70-0.75$. A $10 \%$ return in the U.S. stock market, which previously would have been associated with a $2.7 \%$ return in the Chilean market, would now be associated with a $7.0 \%-7.5 \%$ return in the Chilean market. These calculations are obviously only a rough approximation, but they do suggest that changes in bilateral linkages, and especially bilateral trade flows, can have large effects on how asset market movements are transmitted internationally.

\section{Estimation Results: Global Linkages in Bond Markets}

Next, we repeat the analysis performed in sections $\mathrm{V}$ and VI, but focus on global linkages in bond markets instead of stock markets. As shown in appendix A, data availability for bond markets is much more limited. Therefore, in this section we focus on estimates from 1994-2000 (the full period available). ${ }^{34}$ The different combinations of the global and sectoral factors are the same as used above, but the dependent variable $\left(R_{i t}\right)$ and each of the five cross-country factors are measured as returns for the relevant bond index as discussed in section IV. Summary results for the joint significance of the global, sectoral, and cross-country factors are reported in Figure $2 .{ }^{35}$ The patterns are similar to those for stock returns reported in Figure 1. Cross-country factors continue to be highly significant and more important than global factors in determining market returns. One difference is that sectoral factors appear to be a less important determinant of bond returns than stock returns, especially in Europe.

Of the individual cross-country factors, the U.S. factor is most often significant, for most of the individual regions as

\footnotetext{
${ }^{33}$ Based on local currency stock market returns when equation (1) controls for global and cross-country factors, but not sectoral factors.

${ }^{34}$ Forbes and Chinn (2003) also report results for bond markets during subperiods 1994-1997 and 1998-2000.

${ }^{35} \mathrm{We}$ focus on results based on U.S. dollar returns, instead of local currency, because information for local-currency bond prices is unavailable for many emerging markets.
} 
Figure 2.-Joint Significance of Different Factor Groups-Bond Returns

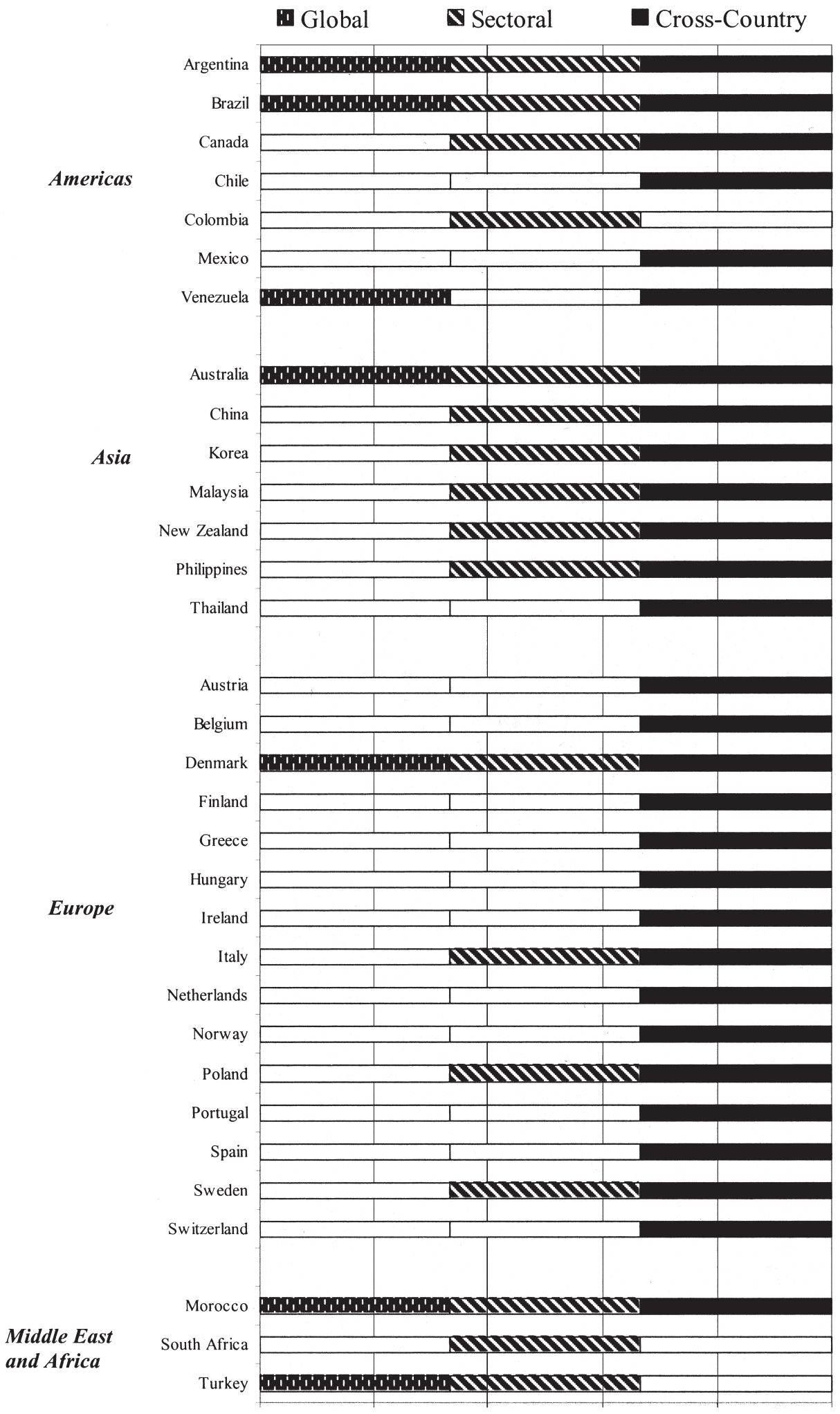


Table 6.-Bilateral Linkage Regressions for Bond Markets: FULL PERIOD 1994-2000

\begin{tabular}{cccccccc}
\hline \hline Factors & $N$ & $R^{2}$ & $\begin{array}{c}\text { Import } \\
\text { Demand }\end{array}$ & $\begin{array}{c}\text { Trade } \\
\text { Comp. }\end{array}$ & $\begin{array}{c}\text { Bank } \\
\text { Lending }\end{array}$ & $\begin{array}{c}\text { Foreign } \\
\text { Invest. }\end{array}$ & $\begin{array}{c}\text { Capital } \\
\text { Controls }\end{array}$ \\
\hline \multicolumn{7}{c}{ Base Results } \\
World & 142 & 0.16 & $3.04^{* *}$ & $-0.92^{* *}$ & $1.41^{*}$ & 6.03 & $0.04^{*}$ \\
$\quad$ market & & $(0.45)$ & $(0.33)$ & $(0.83)$ & $(5.15)$ & $(0.03)$ \\
Full set & 142 & 0.11 & $2.74 * *$ & $-0.98^{* *}$ & $1.46^{*}$ & 7.41 & 0.04 \\
& & & $(0.58)$ & $(0.40)$ & $(0.80)$ & $(5.34)$ & $(0.03)$
\end{tabular}

Capital Controls Measured by Edison-Warnock Statistic ${ }^{\mathrm{b}}$

$\begin{array}{cccccccc}\text { World } & 87 & 0.10 & 2.27 * * & -0.93 & 1.31 & 28.19 * * & 0.10 \\ \text { market } & & & (1.14) & (0.68) & (1.32) & (9.83) & (0.20) \\ \text { Full set } & 87 & 0.07 & 2.16^{* *} & -1.23 & 0.72 & 31.00^{* *} & 0.13 \\ & & & (1.08) & (0.84) & (1.39) & (11.01) & (0.28)\end{array}$

Coefficient estimates of equation (2) for U.S. dollar bond returns. Standard errors in parentheses. ** and * mean significant at the $5 \%$ and $10 \%$ level, respectively.

a "World market" is the residual of the global market return. "Full set" is the full set of 5 global factor (including the global market return) as well as the 14 sectoral factors.

${ }^{\mathrm{b}}$ Capital controls measured by Edison and Warnock's (2003) unsmoothed measure of capital controls.

well as the entire sample. The largest economy (or economies) in each region also continues to be important to neighboring economies, although in most specifications the U.S. factor is more often significant in Asia than the Japanese factor. Another difference between the results for bond returns and the corresponding estimates for stock returns is that excluding the sectoral factors does not have as large an effect on the estimated cross-country factor loadings, especially for the United States and Japan. This difference undoubtedly reflects the fact that the sectoral factors are stock indices, and therefore more highly correlated with stock returns than with bond returns in the major economies.
Next, we decompose the cross-country factor loadings, estimated using the abridged and the full set of control variables, into the four different bilateral linkages as specified in equation (2). Table 6 reports results for U.S. dollar bond returns. The top of the table reports the base results using the same control variables as in section VI. The bottom of the table reports one variant of this base regression-replacing Chinn and Ito's (2002) measure of capital controls with Edison and Warnock's (2003) measure. This alternate specification is included to show the lack of robustness of most of the variables to fairly minor modifications to the base estimates. ${ }^{36}$ The results are similar to those obtained during the later period 1996-2000 in stock markets. The estimated coefficient on Import Demand is always positive and significant. The coefficients on the other three bilateral linkage variables have fluctuating signs and significance. This supports one of the key results from the decomposition of bilateral linkages in stock markets: that one of the primary mechanisms by which movements in large financial markets are transmitted to other markets is through direct trade flows.

\section{Sensitivity Analysis}

This section summarizes an extensive series of sensitivity tests examining if the key conclusions reported above are robust to changes in variable definitions, model specification, control variables, and sample selection. It focuses on

${ }^{36}$ The comparison of the two specifications in table 6 succinctly summarizes the key results from an extensive series of sensitivity tests reported in Forbes and Chinn (2003).

Table 7.-Sensitivity Analysis: Bilateral Linkage Regressions for Stock Returns-1996-2000

\begin{tabular}{|c|c|c|c|c|c|c|c|c|c|}
\hline & & Factors & $N$ & $R^{2}$ & $\begin{array}{l}\text { Import } \\
\text { Demand }\end{array}$ & $\begin{array}{l}\text { Trade } \\
\text { Comp. }\end{array}$ & $\begin{array}{c}\text { Bank } \\
\text { Lending }\end{array}$ & $\begin{array}{l}\text { Foreign } \\
\text { Invest. }\end{array}$ & $\begin{array}{c}\text { Capital } \\
\text { Controls }\end{array}$ \\
\hline & Base case & World market & 149 & 0.22 & $\begin{array}{l}2.03 * * \\
(0.30)\end{array}$ & $\begin{array}{c}-0.49 * * \\
(0.15)\end{array}$ & $\begin{array}{l}0.66^{* *} \\
(0.28)\end{array}$ & $\begin{array}{c}-3.28 * \\
(1.70)\end{array}$ & $\begin{array}{c}-0.00 \\
(0.01)\end{array}$ \\
\hline & E-W capital controls ${ }^{\mathrm{a}}$ & World market & 86 & 0.24 & $\begin{array}{l}1.44 * * \\
(0.67)\end{array}$ & $\begin{array}{c}-0.28 \\
(0.25)\end{array}$ & $\begin{array}{l}2.75^{* *} \\
(0.76)\end{array}$ & $\begin{array}{c}3.37 \\
(7.40)\end{array}$ & $\begin{array}{r}-0.06 \\
(0.08)\end{array}$ \\
\hline & K-S capital controls ${ }^{\mathrm{b}}$ & World market & 91 & 0.20 & $\begin{array}{l}1.73 * * \\
(0.37)\end{array}$ & $\begin{array}{c}-0.49 * * \\
(0.25)\end{array}$ & $\begin{array}{c}0.82 \\
(0.49)\end{array}$ & $\begin{array}{c}-1.71 \\
(4.10)\end{array}$ & $\begin{array}{c}-0.04 \\
(0.06)\end{array}$ \\
\hline (4) & Foreign investment in levels ${ }^{c}$ & World market & 151 & 0.21 & $\begin{array}{l}2.09 * * \\
(0.33)\end{array}$ & $\begin{array}{c}-0.46^{* *} \\
(0.16)\end{array}$ & $\begin{array}{l}0.84 * * \\
(0.27)\end{array}$ & $\begin{array}{r}-0.43 \\
(0.43)\end{array}$ & $\begin{array}{r}-0.01 \\
(0.01)\end{array}$ \\
\hline & Add $c$ fixed effects ${ }^{d}$ & World market & 149 & 0.23 & $\begin{array}{l}2.13 * * \\
(0.39)\end{array}$ & $\begin{array}{c}-0.52 * * \\
(0.19)\end{array}$ & $\begin{array}{c}0.54^{*} \\
(0.30)\end{array}$ & $\begin{array}{c}-3.35 \\
(2.62)\end{array}$ & $\begin{array}{c}-0.00 \\
(0.01)\end{array}$ \\
\hline & Add gravity variables ${ }^{\mathrm{e}}$ & Full set & 149 & 0.24 & $\begin{array}{l}1.44 * * \\
(0.62)\end{array}$ & $\begin{array}{c}-0.64 * * \\
(0.23)\end{array}$ & $\begin{array}{l}1.08 * * \\
(0.32)\end{array}$ & $\begin{array}{c}0.53 \\
(3.12)\end{array}$ & $\begin{array}{r}-0.00 \\
(0.02)\end{array}$ \\
\hline & Add regional dummies ${ }^{f}$ & Full set & 149 & 0.22 & $\begin{array}{l}2.21 * * \\
(0.62)\end{array}$ & $\begin{array}{c}-0.80 * * \\
(0.21)\end{array}$ & $\begin{array}{l}1.43^{* *} \\
(0.37)\end{array}$ & $\begin{array}{c}0.76 \\
(3.06)\end{array}$ & $\begin{array}{c}0.01 \\
(0.02)\end{array}$ \\
\hline & High income countries ${ }^{g}$ & Full set & 84 & 0.29 & $\begin{array}{l}1.95^{* * *} \\
(0.59)\end{array}$ & $\begin{array}{c}-0.77 * * \\
(0.22)\end{array}$ & $\begin{array}{l}1.25^{* *} \\
(0.35)\end{array}$ & $\begin{array}{c}0.74 \\
(2.82)\end{array}$ & $\begin{array}{c}0.07 * \\
(0.04)\end{array}$ \\
\hline (9) & Low \& middle income ${ }^{g}$ & Full set & 65 & 0.16 & $\begin{array}{l}2.52^{* * *} \\
(1.14)\end{array}$ & $\begin{array}{c}-1.31^{* *} \\
(0.56)\end{array}$ & $\begin{array}{c}3.77 * \\
(2.39)\end{array}$ & $\begin{array}{c}14.84 \\
(22.20)\end{array}$ & $\begin{array}{c}0.00 \\
(0.04)\end{array}$ \\
\hline
\end{tabular}

Based on estimates of equation (2) for U.S.-dollar stock returns. Rows 1-5 only control for the global market return in equation (1). Rows 6-9 include the largest set of factors in equation (1): the 5 global factors, 14 sectoral factors, and cross-country factors. Standard errors in parentheses. ** and * mean significant at the $5 \%$ and $10 \%$ level, respectively.

a Capital controls measured by Edison and Warnock's (2003) unsmoothed measure of capital controls.

b Capital controls measured by Kaminsky and Schmukler's (2002) measure of capital account liberalization.

c Foreign investment measured in levels instead of first differences.

${ }^{\mathrm{d}}$ Includes fixed effects for each large country $c$.

' Includes five gravity-equation variables: common borders, common language, former colony, log of distance between countries, and log of the product of real GDPs.

${ }^{\mathrm{f}}$ Includes regional dummy variables for each region as specified in appendix A.

$\mathrm{g}$ Includes only high-income or low-middle-income countries. Definitions based on World Bank (2001). 
results from the bilateral linkage regressions in equation (2), because these results are the key focus of the paper. (The results from the first-stage regressions are also highly robust.) Since most of the bilateral-linkage estimates for the earlier periods for stock markets continue to fluctuate across specifications, we also focus on the robustness of the key results during the later period for stock markets (19962000). Table 7 reports a selection of these results (discussed in detail below) for our preferred specification—-stock markets using period-averaged values. ${ }^{37}$

As an initial series of sensitivity tests, we examine the effect of modifying variable definitions. First, we use two different measures of capital controls: a statistic developed in Edison and Warnock (2003), which is based on restrictions on the foreign ownership of equities, and a statistic developed in Kaminsky and Schmukler (2002), which focuses on capital account regulations. ${ }^{38}$ Results are reported in rows (2) and (3) of table 7. In each case, the sample size shrinks substantially. Second, we use moving-average twoweek returns, instead of weekly returns, to partially adjust for differences in market hours in different countries. Results are virtually unchanged. Third, we redefine the sectoral factors in equation (1) using different sets of sectors, such as the larger set of $36 \mathrm{MSCI}$ sectoral indices. We also include some of the global factors, such as gold and oil, as sectoral factors. Some of these changes affect the relative importance of sets of factors for different countries, and the global factors become even less consistently significant, but the key results discussed above are unchanged.

As a next series of sensitivity tests, we estimate different model specifications. First, we exclude the global factors from equation (1). Second, we focus on a smaller set of cross-country factors and only include one major market from each region (that is, only one of France, Germany, or the United Kingdom as a cross-country factor). Third, we include Foreign Investment in levels (instead of differences), as reported in row (4). We also estimate specifications with the other bilateral linkage variables in differences. Finally, row (5) reports results if we include fixed effects for each large country $c$.

Next, we add a number of additional control variables. First, we include squared and/or cubed terms for each of the bilateral linkage variables as a rough test for any nonlinearities. These additional terms are generally insignificant, and most of the other coefficient estimates become even more fragile (which is not surprising, given the increased multicollinearity in the regressors). Second, we add a number of variables typically included in gravity-equation models (which tend to be highly correlated with bilateral

\footnotetext{
${ }^{37}$ Results for the same set of sensitivity tests for bond markets are equally robust and are reported in table 10 in Forbes and Chinn (2003).

${ }^{38}$ This measure evaluates regulations on offshore borrowing by domestic financial institutions, offshore borrowing by nonfinancial corporations, multiple-exchange-rate markets, and controls on capital outflows.
}

trade) ${ }^{39}$ Many of these variables are individually significant, and including them often reduces the magnitude of the estimated coefficient on Import Demand. As shown in row (6), however, which reports results when five gravity variables are added to the model, the coefficient on Import Demand still remains positive and highly significant. Finally, row (7) adds regional dummy variables.

As a final series of sensitivity tests, we examine the effects of sample selection and outliers. First, we exclude countries that had a banking and/or currency crisis. ${ }^{40}$ The Bank Lending variable is usually insignificant when countries with a banking crisis are excluded from the sample. Second, we exclude oil exporters from the sample. Third, we include only high-income countries or only low-middleincome countries, with income groups based on the definition in World Bank (2001). These results are reported in rows (8) and (9). Finally, we use a number of different measures to exclude outliers.

This series of sensitivity tests (including those not reported in table 9) confirms the central results discussed in sections V through VII. In the bilateral linkage regressions for stock markets in the earlier periods 1985-1990 and 1991-1995, the signs and significance of coefficient estimates fluctuate across specifications. For stock markets in the later period 1996-2000, and bond markets in 19942000, however, the coefficient on Import Demand is consistently positive and highly significant. The coefficient on Bank Lending is positive and significant in approximately two-thirds of the specifications, and is more often significant for stock markets than for bond markets. The coefficient on Trade Competition is negative and significant in approximately two-thirds of the specifications, and is more often significant in bond markets than in stock markets. The coefficient on Foreign Investment is rarely significant. Therefore, in the latter half of the 1990s, direct trade between countries appears to be the most important determinant of how movements in large financial markets affected stock and bond markets around the globe.

\section{Conclusions}

In an effort to better understand why shocks to the world's largest financial markets often spread to some markets while other countries remain relatively insulated, this paper has attempted to answer four questions. First,

\footnotetext{
${ }^{39}$ More specifically, we add combinations of the following five variables: whether the two countries have a common border; whether the two countries have a common language; whether one of the countries was ever colonized by the other country; the natural log of distance between the two countries; and the natural log of the product of the two countries' real GDPs. The geography data are taken from Rose (2002) and are available on Rose's Web site at http://faculty/haas.berkely.edu/arose/. The GDP data are taken from the World Bank's World Development Indicators. See Rose (2002) for further information on gravity-equation models.

${ }^{40}$ Banking crises are defined based on Caprio and Klingebiel's (2001) classification of countries with "systemic banking crises." Currency crises are defined as countries experiencing a $25 \%$ or greater depreciation of their U.S.-dollar exchange rate within any 4-week period.
} 
how important are cross-country linkages with large financial markets, as compared to global and sectoral factors, in explaining financial market returns in countries around the world? To answer this question, we estimated a factor model in which a country's market returns are a function of: cross-country factors (market returns in France, Germany, Japan, the United Kingdom, and the United States) and some combination of global factors (world market returns, global interest rates, oil prices, gold prices, and commodity prices) and/or sectoral factors (stock returns for 14 sectoral indices). We find that both cross-country and sectoral factors are important determinants of stock returns in countries around the world (although it is often difficult to differentiate between these two sets of factors). Not surprisingly, movements in the largest regional economy tend to be the most important cross-country factor for nearby countries, although movements in the U.S. market are also important for most regions. During 1996-2000, the sectoral factors gained importance in most regions.

Second, how important are bilateral trade flows, trade competition in third markets, bank lending, and investment exposure in explaining these cross-country linkages? To answer this question, we decomposed the cross-country linkages estimated in the factor models into these four specific real and financial linkages. Estimates for the full period 1986-2000 had a low degree of explanatory power and were not robust. One of the stronger results was that direct trade (measured by a country's reliance on exports to the largest economies) appears to be one of the most important determinants of cross-country linkages between large economies and markets around the world.

Third, how has the relative importance of these various global linkages changed over time? In order to answer this question, we repeated the above series of estimates for different time periods. In the earlier periods before 1996, bilateral linkages continue to have a low degree of explanatory power, and estimates are highly sensitive to model specification. From 1996 to 2000, however, bilateral linkages through trade and finance become substantially more important determinants of how shocks are transmitted from large economies to markets around the world. More specifically, direct trade flows appear to be the strongest and most important determinant of cross-country linkages. Rough estimates suggest that the magnitude of these effects can be large. Bank lending and trade competition in third markets can also be significant, although results fluctuate across specifications. Foreign investment, however, does not appear to be a significant determinant of cross-country linkages in any period.

Fourth and finally, how does the relative importance of these global linkages differ between stock markets and bond markets? In order to answer this question, we repeat the same series of estimates discussed above, but focus on linkages in bond markets instead of stock markets. We find that most of the key results are unchanged. For example, cross-country factors continue to be highly significant and more important than global factors in determining market returns. Of the individual cross-country factors, the U.S. factor is most often significant. When the cross-country linkages are decomposed into real and financial linkages, bilateral trade continues to be the only variable that is consistently significant. Therefore bilateral trade flows appears to be the most important determinant of cross-country linkages in bond markets as well as stock markets.

Although this paper has addressed a range of questions, this analysis is only a start. Many of these questions could be extended in a number of different directions. For example, does the importance of various types of global linkages differ between crisis periods and the longer time periods investigated in this paper? Does it differ according to the type of shocks affecting large economies? Do these results on the relationships between large and small economies also apply to pairs of smaller economies? And last, but certainly not least, what is the importance of other types of bilateral linkages (such as portfolio investment and multinational exposure) that are not included in this analysis?

Despite these remaining questions, the paper has documented a number of factors determining why movements in large financial markets can have substantial effects on countries around the world. The decomposition of bilateral linkages in both stock and bond markets reaches the same conclusion: that the primary mechanism by which shocks to the largest financial markets were transmitted internationally in the latter part of the 1990s was through direct trade flows. These results suggest that despite the recent growth in capital flows across countries, direct trade linkages are still more important than financial linkages in determining how shocks to the world's largest economies affect a variety of markets around the globe. Finally, these results document that real linkages between countries, even when measured at an annual frequency, can be large and important determinants of higher-frequency movements in financial markets.

\section{REFERENCES}

Bekaert, Geert, and Campbell R. Harvey, "Research in Emerging Markets Finance: Looking to the Future," Emerging Markets Review 3 (2002), 429-448.

Breitung, Jorg, and Wolfgang Meyer, "Testing for Unit Roots in Panel Data: Are Wages on Different Bargaining Levels Cointegrated?" Applied Economics 26 (1994), 353-361.

Brooks, Robin, and Marco Del Negro, "The Rise in Comovement across National Stock Markets: Market Integration or Global Bubble?" IMF working paper no. 02/147 (2002).

"Firm-level Evidence on Globalization," IMF working paper no. 03/55 (2003).

Caprio, Gerard, and Daniela Klingebiel, "Episodes of Systemic and Borderline Financial Crises," World Bank mimeograph (2001).

Chinn, Menzie D., and Hiro Ito, "Capital Account Liberalization, Institutions and Financial Development: Cross Country Evidence," NBER working paper no. 8967 (2002).

Claessens, Stijn, Rudiger Dornbusch, and Yung Chul Park, "Contagion: Why Crises Spread and How This Can Be Stopped" (pp. 19-41), in S. Claessens and K. Forbes (Eds.), International Financial Contagion (Boston: Kluwer Academic Publishers, 2001).

Claessens, Stijn, and Kristin J. Forbes (Eds.), International Financial Contagion (Boston: Kluwer Academic Publishers, 2001). 
Dominguez, Kathryn, and Linda Tesar, "Exchange Rate Exposure," NBER working paper no. 8453 (2001).

Edison, Hali J., and Francis E. Warnock, "A Simple Measure of the Intensity of Capital Controls," Journal of Empirical Finance 10 (2003), 81-103.

Eichengreen, Barry, and Andrew Rose (1999). "Contagious Currency Crises: Channels of Conveyance" (pp. 29-50), in T. Ito and A. Krueger (Eds.), Changes in Exchange Rates in Rapidly Developing Countries: Theory, Practice, and Policy Issues (Chicago: University of Chicago Press, 1999).

Elliott, Graham, Thomas J. Rothenberg, and James H. Stock, "Efficient Tests for an Autoregressive Unit Root," Econometrica 64 (1996), 813-836.

Forbes, Kristin J., "The Asian Flu and Russian Virus: Firm-Level Evidence on How Crises Are Transmitted Internationally," Journal of International Economics 63 (2004), 59-92.

"Are Trade Linkages Important Determinants of Country Vulnerability to Crises?" (pp. 77-124), in S. Edwards and J. A. Frankel (Eds.), Preventing Currency Crises in Emerging Markets (Chicago: National Bureau of Economic Research, 2002).

Forbes, Kristin J., and Menzie D. Chinn, "A Decomposition of Global Linkages in Financial Markets over Time," NBER working paper no. 9555 (2003).

Forbes, Kristin J., and Roberto Rigobon, "No Contagion, Only Interdependence: Measuring Stock Market Comovements," The Journal of Finance LVII (2002), 2223-2261.

Glick, Reuven, and Andrew Rose, "Contagion and Trade: Why Are Currency Crises Regional?" Journal of International Money and Finance 18 (1999), 603-617.

Goldfajn, Ilan, and Rodrigo Valdés, "Capital Flows and Twin Crises: The Role of Liquidity," IMF working paper no. 97/87 (1997).

Imbs, Jean, "Trade, Finance, Specialization, and Synchronization," IMF working paper no. 03/81 (2003).

Kaminsky, Graciela, Richard Lyons, and Sergio Schmukler, "Mutual Fund Investment in Emerging Markets: An Overview" (pp. 158-185), in S. Claessens and K. Forbes (Eds.), International Financial Contagion (Boston: Kluwer Academic Publishers, 2001).

Kaminsky, Graciela, and Sergio Schmukler, "Short-Run Pain, Long-Run Gain: The Effects of Financial Liberalization," World Bank working paper no. 2912 (2002)

Karolyi, G. Andrew, "The Role of ADRs in the Development and Integration of Emerging Equity Markets," this REVIEW, this issue.

Karolyi, G. Andrew, and René M. Stulz, "Are Financial Assets Priced Locally or Globally?" in G. Constantinides, M. Harris, and R. M. Stulz (Eds.), Handbook of the Economics of Finance (Amsterdam: North Holland, 2003).

Kose, M. Ahyan, Christopher Otrok, and Charles Whiteman, "Understanding the Evolution of World Business Cycles," IMF mimeograph (2003).

Mody, Ashoka, Assaf Razin, and Efraim Sadka, "The Role of Information in Driving FDI: Theory and Evidence," NBER working paper no. 9255 (2002).

OECD, International Direct Statistics Yearbook (2001).

Pantula, S. G., G. Gonzalez-Farias, and W. A. Fuller, "A Comparison of Unit-Root Test Criteria," Journal of Business and Economics Statistics 12 (1994), 449-459.

Peek, Joe, and Eric Rosengreen, "The International Transmission of Financial Shocks: The Case of Japan," American Economic Review 87 (1997), 495-505.

Roll, Richard, "Industrial Structure and the Comparative Behavior of International Stock Market Indices," The Journal of Finance 47 (1992), 3-41.

Rose, Andrew, "Do We Really Know That the WTO Increases Trade?" NBER working paper no. 9273 (2002).

Stock, James H., "Unit Roots, Structural Breaks, and Trends," in R. F. Engle and D. I. McFadden (Eds.), Handbook of Econometrics (Amsterdam: North-Holland, 1994).

Van Rijckeghem, Caroline, and Beatrice Weder, "Sources of Contagion: Is it Finance or Trade?" Journal of International Economics 54 (2001), 293-308.

"Spillovers through Banking Centers: A Panel Data Analysis," Journal of International Money and Finance 22 (2003), 483-509.

World Bank, World Development Report 2000/2001 (Washington, DC: Oxford University Press, 2001).

\section{APPENDIX A}

Sample Coverage

TABLE $\mathrm{A} 1^{\mathrm{a}}$

\begin{tabular}{|c|c|c|c|c|}
\hline \multirow[b]{2}{*}{ Region } & \multirow[b]{2}{*}{ Country $i$} & \multirow{2}{*}{$\begin{array}{l}\text { Stock Market } \\
\text { Regressions }^{\text {b }}\end{array}$} & \multicolumn{2}{|c|}{ Bond Market Regressions } \\
\hline & & & U.S. Dollars & Local Currency \\
\hline \multirow[t]{7}{*}{ Americas } & Argentina & 1989-2000 & 1994-2000 & - \\
\hline & Brazil & 1995-2000 & 1994-2000 & - \\
\hline & Canada & 1985-2000 & 1994-2000 & 1994-2000 \\
\hline & Chile & 1990-2000 & 1999-2000 & - \\
\hline & Colombia & $1993-2000$ & 1997-2000 & - \\
\hline & Mexico & 1989-2000 & 1994-2000 & - \\
\hline & Venezuela & 1991-2000 & 1994-2000 & - \\
\hline \multirow[t]{11}{*}{ Asia } & Australia & $1985-2000$ & 1994-2000 & 1994-2000 \\
\hline & China & 1994-2000 & 1994-2000 & - \\
\hline & Hong Kong & 1985-2000 & - & - \\
\hline & India & 1991-2000 & - & - \\
\hline & Indonesia & 1991-2000 & - & - \\
\hline & Korea (South) & 1988-2000 & 1994-2000 & - \\
\hline & Malaysia & 1987-2000 & 1996-2000 & - \\
\hline & New Zealand & 1989-2000 & 1994-2000 & 1994-2000 \\
\hline & Philippines & 1988-2000 & 1994-2000 & - \\
\hline & Singapore & $1985-2000$ & - & - \\
\hline & Thailand & 1988-2000 & 1997-2000 & - \\
\hline \multirow[t]{16}{*}{ Europe } & Austria & $1985-2000$ & 1994-2000 & 1994-2000 \\
\hline & Belgium & 1985-2000 & 1994-2000 & 1994-2000 \\
\hline & Denmark & $1985-2000$ & 1994-2000 & 1994-2000 \\
\hline & Finland & 1989-2000 & 1994-2000 & 1994-2000 \\
\hline & Greece & 1989-2000 & 1997-2000 & 1997-2000 \\
\hline & Hungary & 1992-2000 & 1999-2000 & - \\
\hline & Iceland & 1994-2000 & - & - \\
\hline & Ireland & 1985-2000 & 1994-2000 & 1994-2000 \\
\hline & Italy & 1985-2000 & 1994-2000 & 1994-2000 \\
\hline & Netherlands & $1985-2000$ & 1994-2000 & 1994-2000 \\
\hline & Norway & $1985-2000$ & 1994-2000 & 1994-2000 \\
\hline & Poland & 1995-2000 & 1994-2000 & - \\
\hline & Portugal & 1991-2000 & 1994-2000 & 1994-2000 \\
\hline & Spain & $1988-2000$ & 1994-2000 & 1994-2000 \\
\hline & Sweden & $1985-2000$ & 1994-2000 & 1994-2000 \\
\hline & Switzerland & 1985-2000 & 1994-2000 & 1994-2000 \\
\hline Middle East & Israel & 1994-2000 & - & - \\
\hline \multirow[t]{3}{*}{ \& Africa } & Morocco & - & 1994-2000 & - \\
\hline & South Africa & 1985-2000 & 1995-2000 & 1995-2000 \\
\hline & Turkey & 1989-2000 & 1996-2000 & - \\
\hline
\end{tabular}

a France, Germany, Japan, the United Kingdom, and the United States are included as large countries indexed by $c$ and therefore excluded from the list of smaller countries indexed by $i$.

${ }^{\mathrm{b}}$ Includes stock returns expressed in both local currency and U.S. dollars.

\section{APPENDIX B}

\section{Unit Root Testing}

There are two standard approaches to determine if variables are stationary: conduct unit root tests series by series, or employ recently developed panel unit root tests. Each of these approaches is complicated by the nature of the data set described in section IV. The series-by-series approach is hampered by the extremely short time span of the data (16 observations at most). The panel approach is complicated by the fact that the panels are much wider than they are long (that is, the number of observations, $N$, is much larger than the number of periods, $T$ ). Hence, we examine results from both sets of tests. ${ }^{41}$

${ }^{41}$ See Appendix C of Forbes and Chinn (2003) for equations and additional details on these testing methodologies. 


\section{The Series-by-Series Analysis}

First, we use a modified Dickey-Fuller test known as the ADF-GLS test to test for stationarity. ${ }^{42}$ Whereas the standard Dickey-Fuller procedure is notorious for its low power, the ADF-GLS test has been shown to be approximately uniformly most powerful invariant. ${ }^{43}$ We use a variant of the tests that allows for a linear time trend. The unit root hypothesis is rejected when the ADF-GLS test statistic is significant.

Using this test, we find that the cross-country factor loadings reject the unit root null with the greatest frequency. For instance, $50 \%$ of the factor loadings (that is, the $\beta$ 's) estimated using sectoral indices and U.S. dollar stock returns reject the null hypothesis (using a 10\% significance threshold). In other words, the unit root null is rejected at rates much higher than would be expected to occur randomly. Turning to the bilateral linkage variables, 34\% and 30\% of the Import Demand and Trade Competition series reject the unit root null. The Bank Lending and Foreign Investment series exhibit lower rejection rates of $26 \%$ and $27 \%$, respectively. These tests suggest that all of the variables are stationary, although the results for the financial variables are weakest.

\section{The Panel Unit Root Test}

We use a likelihood ratio test advanced by Breitung and Meyer (1994), mainly because it is the most appropriate test for panel data sets where the time dimension $(T)$ is much smaller than the cross-sectional dimension $(N)$. The results are reported in Table B1 and include tests for estimates both with and without the sectoral effects and for different combinations of financial markets and currencies. Overall, there is strong evidence of reversion for almost all of the cross-country factor loadings. Only one of these cases is unable to reject nonstationarity, and the number of observations for that test is substantially smaller, reducing the test's power.

For the bilateral linkage variables, test results clearly indicate that the Trade Competition and Bank Lending series are stationary. Although the evidence for the Import Demand series is somewhat weaker (and the test statistic is insignificant), the reversion coefficient is still negative. Moreover, results from the series-by-series tests rejected the unit root null for this series, so we treat Import Demand as stationary in the base regressions. In stark contrast, the positive and statistically significant coefficient on the Foreign Investment series indicates that this series is nonstationary. Foreign Investment also had one of the lowest rejection rates of station-

${ }^{42}$ See Elliott, Rothenberg, and Stock (1996) for a more detailed description of this testing procedure.

${ }^{43}$ For example, see Pantula, Gonzalez-Farias, and Fuller (1994) and Stock (1994). arity in the series-by-series tests. We also examine the first difference of Foreign Investment, and this test strongly rejects the presence of a unit root. Therefore, in the main regression analysis, we treat all of the variables as stationary except Foreign Investment.

Table B1.-Panel Unit Root Tests

\begin{tabular}{|c|c|c|c|}
\hline Variable & $\alpha_{0}$ & $N$ & Adj. $R^{2}$ \\
\hline \multicolumn{4}{|c|}{ Betas-with Sectoral Factors } \\
\hline Stock returns in U.S. \$ & $\begin{array}{c}-0.059^{* *} \\
(0.013)\end{array}$ & 2057 & 0.28 \\
\hline Stock returns in local currency & $\begin{array}{c}-0.014 * \\
(0.008)\end{array}$ & 2057 & 0.13 \\
\hline Bond returns in U.S. \$ & $\begin{array}{c}-0.317 * * \\
(0.040)\end{array}$ & 675 & 0.30 \\
\hline Bond returns in local currency & $\begin{array}{c}-0.010 \\
(0.028)\end{array}$ & 405 & 0.21 \\
\hline \multicolumn{4}{|c|}{ Betas-without Sectoral Factors } \\
\hline Stock returns in U.S. \$ & $\begin{array}{c}-0.213 * * \\
(0.018)\end{array}$ & 2060 & 0.36 \\
\hline Stock returns in local currency & $\begin{array}{c}-0.233 * * \\
(0.018)\end{array}$ & 2060 & 0.30 \\
\hline Bond returns in U.S. \$ & $\begin{array}{c}-0.395^{* *} \\
(0.044)\end{array}$ & 680 & 0.39 \\
\hline Bond returns in local currency & $\begin{array}{c}-0.407 * * \\
(0.063)\end{array}$ & 405 & 0.23 \\
\hline \multicolumn{4}{|c|}{ Bilateral Linkage Variables } \\
\hline Import demand & $\begin{array}{c}-0.007 \\
(0.005)\end{array}$ & 10,644 & 0.01 \\
\hline Trade competition & $\begin{array}{c}-0.021 * * \\
(0.005)\end{array}$ & 10,644 & 0.03 \\
\hline Bank lending & $\begin{array}{c}-0.041 * * \\
(0.005)\end{array}$ & 5657 & 0.07 \\
\hline Foreign investment & $\begin{array}{l}0.047 * * \\
(0.007)\end{array}$ & 4361 & 0.05 \\
\hline Differenced foreign investment & $\begin{array}{c}-0.185^{* * *} \\
(0.016)\end{array}$ & 3804 & 0.32 \\
\hline
\end{tabular}

$* *$ and * denote significance at the $5 \%$ and $10 \%$ levels, respectively. 